\title{
Communication
}

\section{Design, Synthesis and Evaluation of New Indolylpyrimidylpiperazines for Gastrointestinal Cancer Therapy}

\author{
Aaron Tan ${ }^{1}{ }^{(}$, , Maria V. Babak ${ }^{2}{ }^{\oplus}$, Gopalakrishnan Venkatesan ${ }^{2}$, Clarissa Lim ${ }^{2}$, \\ Karl-Norbert Klotz ${ }^{3}{ }^{\oplus}$, Deron Raymond Herr ${ }^{4} \oplus$, Siew Lee Cheong ${ }^{5, *}$, Stephanie Federico ${ }^{6}$, \\ Giampiero Spalluto ${ }^{6}$, Wei-Yi Ong ${ }^{7}$, Yu Zong Chen ${ }^{2}$, Jason Siau Ee Loo ${ }^{8, * \mathbb{D}}$ and \\ Giorgia Pastorin 1,2,*(D) \\ 1 NUS Graduate School of Integrative Sciences and Engineering, National University of Singapore, Centre for \\ Life Sciences, \#05-01, 28 Medical Drive, Singapore 117456, Singapore; aarontan@u.nus.edu \\ 2 Department of Pharmacy, National University of Singapore, Singapore 119260, Singapore; \\ maria.babak@nus.edu.sg (M.V.B.); phagove@nus.edu.sg (G.V.); scifryc@nus.edu.sg (C.L.); \\ csccyz@nus.edu.sg (Y.Z.C.) \\ 3 Institut für Pharmakologie und Toxikologie, Universität Würzburg, 97078 Würzburg, Germany; \\ klotz@toxi.uni-wuerzburg.de \\ 4 Department of Pharmacology, National University of Singapore, Singapore 117600, Singapore; \\ phcdrh@nus.edu.sg \\ 5 Department of Pharmaceutical Chemistry, School of Pharmacy, International Medical University, \\ 126 Jalan Jalil Perkasa 19, Bukit Jalil, Kuala Lumpur 57000, Malaysia \\ 6 Dipartimento di Scienze Chimiche e Farmaceutiche, Università degli Studi di Trieste, 34127 Trieste, Italy; \\ sfederico@units.it (S.F.); spalluto@units.it (G.S.) \\ 7 Department of Anatomy, National University of Singapore, Singapore 119260, Singapore; \\ antongwy@nus.edu.sg \\ 8 School of Pharmacy, Faculty of Health and Medical Sciences, Taylor's University, 1, Jalan Taylors, \\ Subang Jaya, Selangor 47500, Malaysia \\ * Correspondence: CheongSiewLee@imu.edu.my (S.L.C.); JasonSiauEe.Loo@taylors.edu.my (J.S.E.L.); \\ phapg@nus.edu.sg (G.P.)
}

Academic Editor: Loredana Cappellacci

Received: 20 September 2019; Accepted: 8 October 2019; Published: 11 October 2019

\begin{abstract}
Human $\mathrm{A}_{3}$ adenosine receptor $\mathrm{h} \mathrm{A}_{3} \mathrm{AR}$ has been implicated in gastrointestinal cancer, where its cellular expression has been found increased, thus suggesting its potential as a molecular target for novel anticancer compounds. Observation made in our previous work indicated the importance of the carbonyl group of amide in the indolylpyrimidylpiperazine (IPP) for its human $\mathrm{A}_{2 \mathrm{~A}}$ adenosine receptor $\left(\mathrm{hA}_{2 \mathrm{~A}} \mathrm{AR}\right)$ subtype binding selectivity over the other AR subtypes. Taking this observation into account, we structurally modified an indolylpyrimidylpiperazine (IPP) scaffold, 1 (a non-selective adenosine receptors' ligand) into a modified IPP (mIPP) scaffold by switching the position of the carbonyl group, resulting in the formation of both ketone and tertiary amine groups in the new scaffold. Results showed that such modification diminished the $\mathrm{A}_{2 \mathrm{~A}}$ activity and instead conferred $\mathrm{hA}_{3} \mathrm{AR}$ agonistic activity. Among the new mIPP derivatives (3-6), compound 4 showed potential as a $\mathrm{hA}_{3} \mathrm{AR}$ partial agonist, with an $\mathrm{E}_{\max }$ of $30 \%$ and $\mathrm{EC}_{50}$ of $2.89 \pm 0.55 \mu \mathrm{M}$. In the cytotoxicity assays, compound 4 also exhibited higher cytotoxicity against both colorectal and liver cancer cells as compared to normal cells. Overall, this new series of compounds provide a promising starting point for further development of potent and selective $\mathrm{hA}_{3} \mathrm{AR}$ partial agonists for the treatment of gastrointestinal cancers.
\end{abstract}

Keywords: gastrointestinal cancer; $\mathrm{hA}_{3} \mathrm{AR}$; partial agonists; indolylpyrimidylpiperazines 


\section{Introduction}

Gastrointestinal (GI)-related cancers are pathological conditions that account for at least 30\% of cancer-related deaths worldwide [1]. Among them, liver cancer has shown an increasing incidence, which is projected to rise by $35 \%$ by 2030 [2]. Colorectal cancer is also becoming a predominant cancer worldwide, with 746,300 and 614,300 new cases reported in 2012 among men and women, respectively [3]; its incidence and death rates are projected to rise by $60 \%$ by 2030 [4]. This projection is indicative of colorectal cancer becoming the cancer with the highest incidence and the second most prevalent cause of cancer-related deaths by 2030.

The current chemotherapeutic options for colorectal cancers are limited. Nonetheless, a study conducted by Bar-Yehuda et al. showed that a human $\mathrm{A}_{3}$ adenosine receptor $\left(\mathrm{h} \mathrm{A}_{3} \mathrm{AR}\right)$-selective agonist, CF101 (IB-MECA), was able to enhance the chemotherapeutic efficacy of 5-fluorouracil in a colon carcinoma murine model. Sakowicz-Burkiewicz et al. also observed that the treatment of HCT-116 human colorectal carcinoma cells with CF101 had resulted in an increase in apoptosis and necrosis of the cancer cells [5]. Aphase II clinical trial on human colon carcinoma patients showed CF101 exhibiting disease stabilization potential in 35\% of the patients [6]. In addition, CF101 also exhibited a myeloprotective effect in the murine model [7], suggesting improved tolerability and decreased side effects. From these studies, it emerges that the activation of the $\mathrm{hA}_{3} \mathrm{AR}$ clearly plays a crucial role in tumour progression: this receptor is overexpressed in several pathological conditions [8] such as colorectal cancer [9,10], breast cancer [10,11], brain cancer [12] and leukaemia [13]. Patients suffering from colorectal cancer were also reported to have a higher expression level of the $\mathrm{hA} \mathrm{A}_{3} \mathrm{AR}$ at the tumour site as compared to adjacent, remote, and healthy colon mucosa. Furthermore, the level of upregulation of $\mathrm{hA}_{3} \mathrm{AR}$ was found to be directly correlated to the disease severity [9], making it a representative biomarker for colorectal cancer.

Similarly, poor prognosis is associated with advanced stage liver cancer patients, where drugs such as doxorubicin and cisplatin do not exhibit improved survival rate (as observed in various phase III clinical trials) and are accompanied with significant toxicity [14]. Hence, many research groups are exploring new molecular targets for advanced stages of liver cancer. One current phase II clinical trial is investigating the use of CF102 (2-Cl-IB-MECA), a hA 3 AR-selective agonist, to improve the overall survival rate of advanced liver cancer patients while maintaining a low toxicity profile. Earlier phase I/II clinical trials on 18 advanced stage liver cancer patients showed that a patient who developed metastases prior to CF102 treatment had achieved a complete metastasis regression during the three-month treatment with CF102 [15]. The success of both CF101 and CF102 demonstrate the potential for selective $\mathrm{hA}_{3} \mathrm{AR}$ agonists.

In our previous work, we had developed a $\mathrm{hA}_{2 \mathrm{~A}} \mathrm{AR}$-selective ligand, 1. An observation based on such work indicated that a simple chemical modification in the scaffold of $\mathbf{1}$ was able to convert a selective $\mathrm{hA}_{2 \mathrm{~A}} \mathrm{AR}$ ligand with $\mathrm{K}_{\mathrm{i}} \mathrm{hA}_{2 \mathrm{~A}} \mathrm{AR}=8.71 \mu \mathrm{M}$ and selectivity $\mathrm{hA} \mathrm{A}_{2 \mathrm{~A}} \mathrm{AR} / \mathrm{hA} \mathrm{A}_{3} \mathrm{AR}>12$ into a

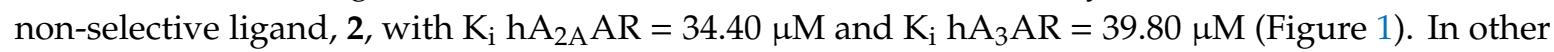
words, the simple removal of the carbonyl group of amide in $\mathbf{1}$ had led to the loss of binding selectivity towards the $\mathrm{hA}_{2 \mathrm{~A}} \mathrm{AR}[16]$.

In continuation to the previous studies, we aimed to investigate the effect of switching the position of the carbonyl group on indolylpyrimidylpiperazine (IPP) towards the activity at both $\mathrm{A}_{2 \mathrm{~A}}$ and $\mathrm{A}_{3}$ receptors in our present work. Hence, we carried out structural modifications of IPP (1) by shifting the carbonyl group to the position adjacent to the indole ring as shown in the modified IPP (mIPP), 3, producing both a ketone group and a tertiary amine group in the new scaffold. It is postulated that such modification would eventually diminish the $A_{2 A}$ activity while gaining activity at the $A_{3}$ receptor. Based on the mIPP scaffold, 3, we introduced different substituents on the 7th position of the indole ring, generating the series of compounds, 4-6 (shown in Figure 2). 


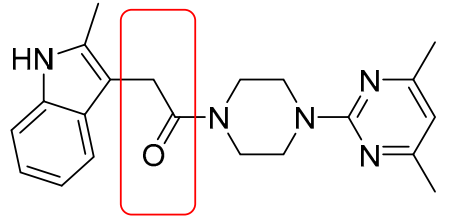

1

$\mathrm{Ki} \mathrm{hA}_{1}>100 \mu \mathrm{M}$

$\mathrm{KinA}_{2 \mathrm{~A}}=8.71 \mu \mathrm{M}$

$\mathrm{Ki} \mathrm{hA}_{2 B}>20 \mu \mathrm{M}$

$\mathrm{KinA}_{3}>100 \mu \mathrm{M}$

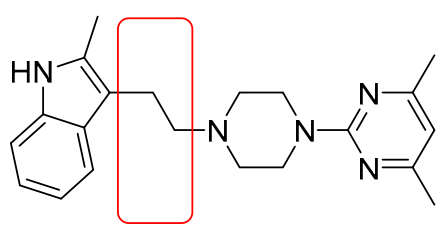

2

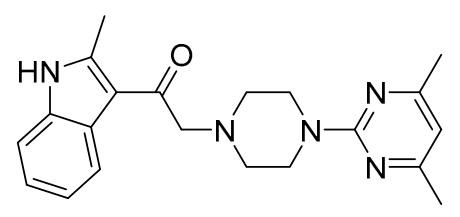

3

Figure 1. Experimental binding affinities of indolylpyrimidylpiperazine (IPP) (1) and decarbonyl IPP (2). Modified IPP (mIPP) (3) scaffold was derived upon shifting of carbonyl group to the position next to the indole moiety of IPP.

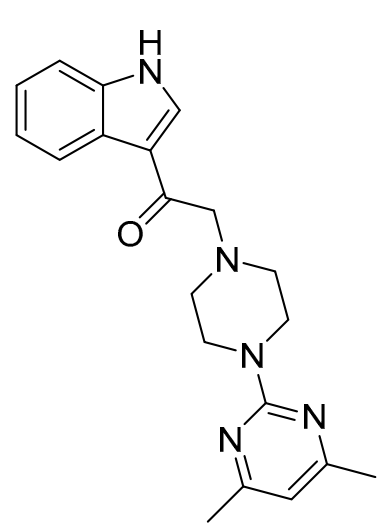

3<smiles>C=CC=CCCCN1CCN(c2nc(C)cc(C)n2)CC1</smiles>

4<smiles>Cc1cc(C)nc(N2CCN(CC(=O)c3c[nH]c4c(Cl)cccc34)CC2)n1</smiles>

5<smiles>Cc1cc(C)nc(N2CCN(CC(=O)c3c[nH]c4c([N+](=O)[O-])cccc34)CC2)n1</smiles>

6

Figure 2. Structure of compound 3 and its derivatives (4-6) bearing substituents on 7 th position of the indole ring.

\section{Results and Discussion}

\subsection{Chemistry}

Compound 3 was synthesized based upon the synthetic scheme (Scheme 1), in which indole was treated dropwise with chloroacetylchloride in the presence of pyridine for an hour at $60{ }^{\circ} \mathrm{C}$ in dioxane to give 2-chloro-1-(1H-indol-3-yl)ethanone (7), with a yield of 50\% [17].

The same synthetic scheme could not be applied for the synthesis of compounds $4-6$, as the substituted chloroacetylindoles could not be produced using the same reaction condition as for the synthesis of compound 7. 


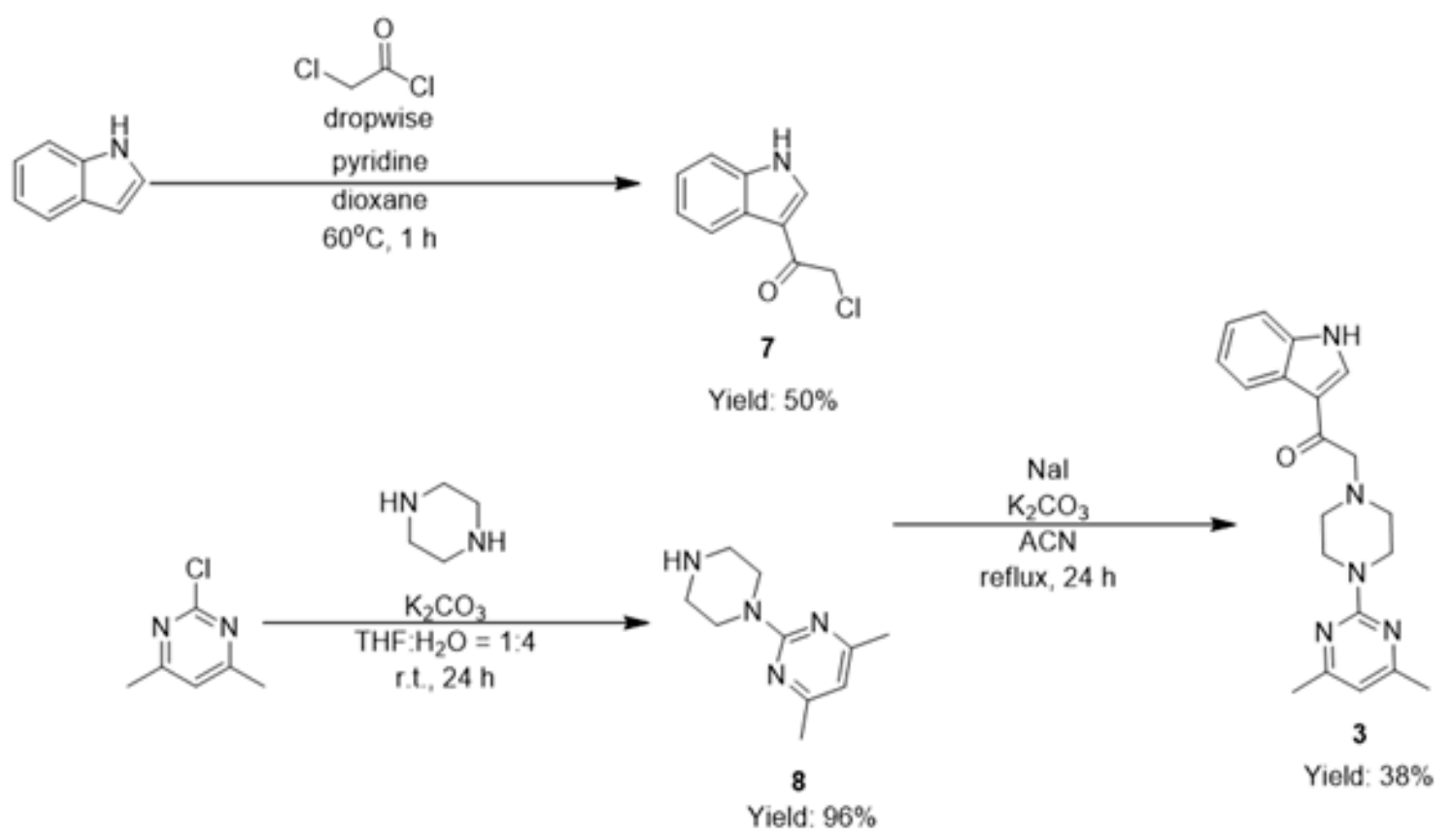

Scheme 1. Synthetic scheme for the synthesis of compound 3.

Compounds 4 and 5 were synthesized based on the synthetic scheme (Scheme 2), where both 7-methoxyindole and 7-chloroindole were treated with chloroacetylchloride in the presence of 1,8-diazabicyclo(5.4.0)undec-7-ene (DBU) under a pressurized reaction condition in dichloroethane (DCE) at $90^{\circ} \mathrm{C}$ for a reaction period of 2-5 days to afford 2-chloro-1-(7-methoxy-1H-indol-3-yl)ethanone (9) and 2-chloro-1-(7-chloro-1H-indol-3-yl)ethanone (10) in 23\% and 11\% yield, respectively [18].

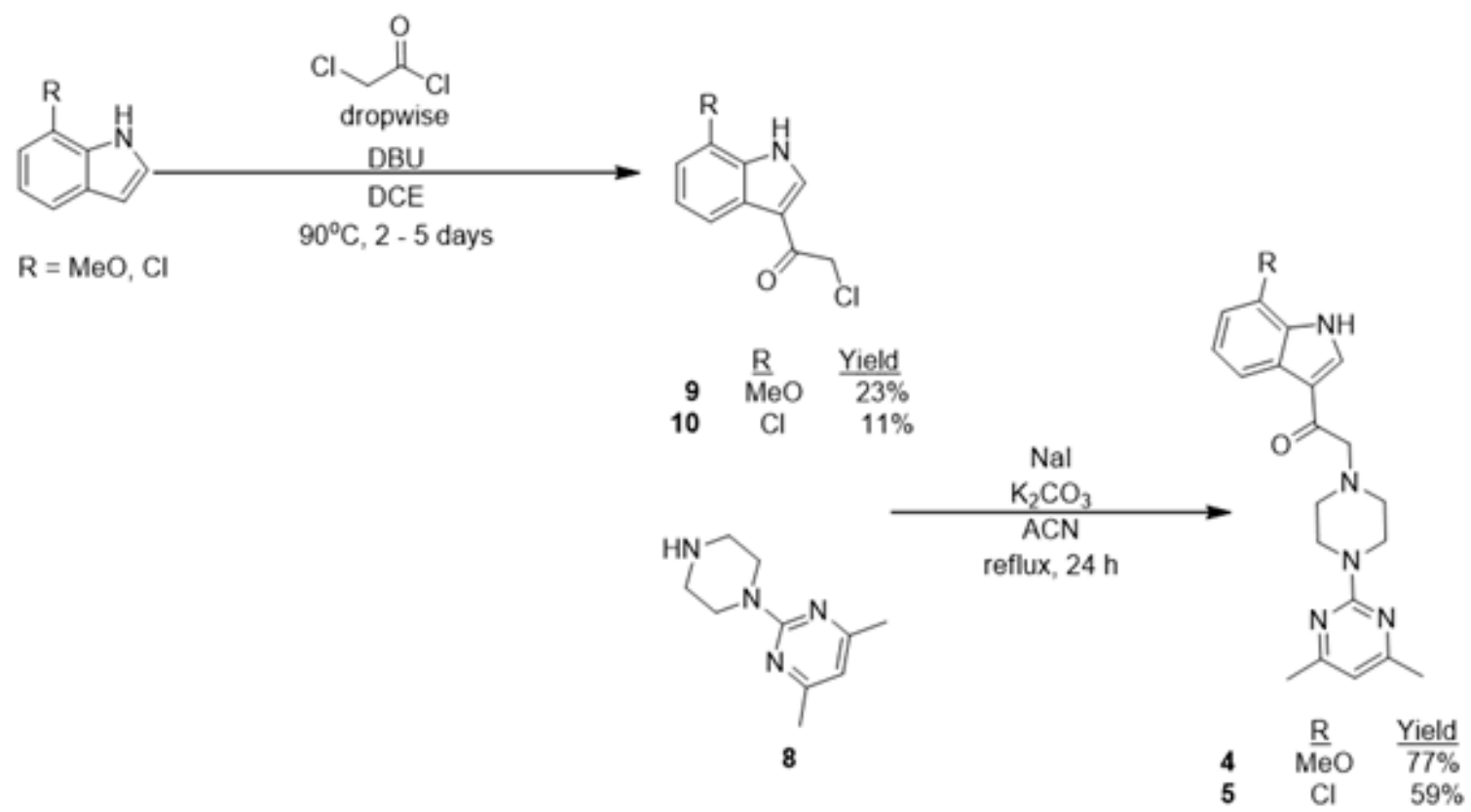

Scheme 2. Synthetic scheme for the synthesis of compounds 4 and 5.

Compound 6 was obtained through the Vilsmeier-Haack acylation for synthesis of compound 12, 2-chloro-1-(7-nitro-1H-indol-3-yl)ethenone, as presented in Scheme 3. 2-Chloro- $\mathrm{N}, \mathrm{N}$-dimethylacetamide (11) was first synthesized from chloroacetyl chloride and dimethylamine hydrochloride salt in the presence of triethylamine (TEA) and was subsequently used in a Vilsmeier-Haack acylation 
of 7-nitroindole in the presence of phosphoryl oxychloride at room temperature for $18 \mathrm{~h}$ to give 2-chloro-1-(7-nitro-1H-indol-3-yl)ethenone (12) with a yield of 17\% [19].

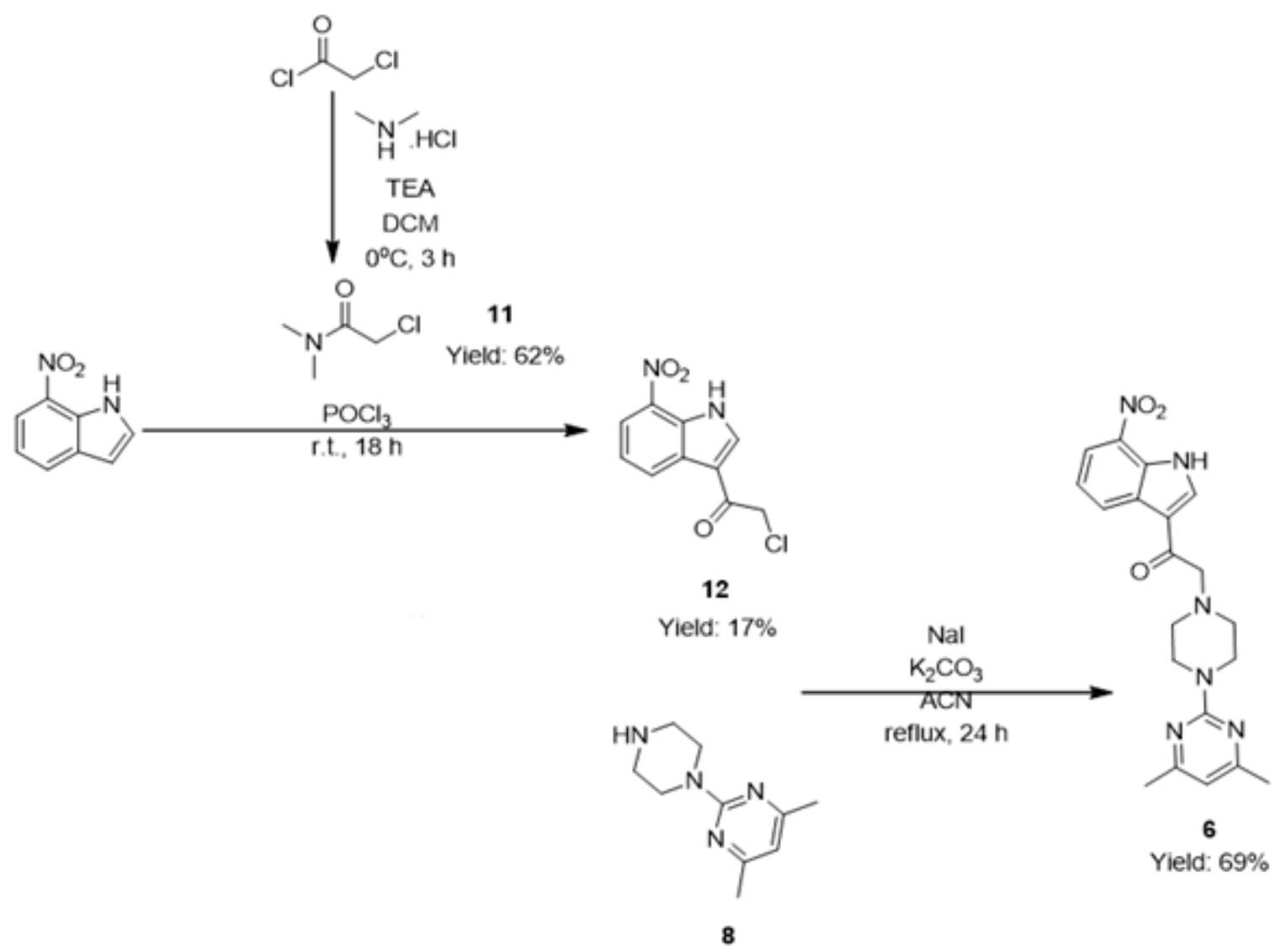

Scheme 3. Synthetic scheme for the synthesis of compound 6 .

To minimize the formation of 2-[4-(4,6-dimethylpyrimidin-2-yl)piperazin-1-yl]-4,6-dimethylpyrimidine, five equivalents of piperazine were reacted with one equivalent of 2-chloro-4,6-dimethylpyrimdine in a solvent mixture of tetrahydrofuran (THF) and water with a ratio of 1:4 at room temperature for $24 \mathrm{~h}$ in the presence of base to give 4,6-dimethyl-2-(piperazin-1-yl)pyrimidine (8) with a yield of $96 \%$ (Scheme 1) [20].

Compounds 3-6 were then obtained from reaction between compound 8 and their respective chloroacetylindoles 7, 9, 10 and 12 in the presence of sodium iodide and base under reflux for $24 \mathrm{~h}$, with respective yields of $38 \%, 77 \%, 59 \%$ and $69 \%$ [21].

\subsection{Biological Evaluation}

\subsubsection{Functional Activity Studies at $h \mathrm{~A}_{2 \mathrm{~A}} \mathrm{AR}$ and $\mathrm{h} \mathrm{A}_{3} \mathrm{AR}$}

Functional activity of compounds 3-6 was determined using the transforming growth factor alpha $\left(\mathrm{TGF}_{\alpha}\right)$ shedding assay. This recently-developed assay utilizes an alkaline phosphatase-TGF $\alpha$ fusion protein reporter system to quantitatively evaluate specific GPCR-mediated G protein activation (shown in Figure 3) of test compounds [22]. 


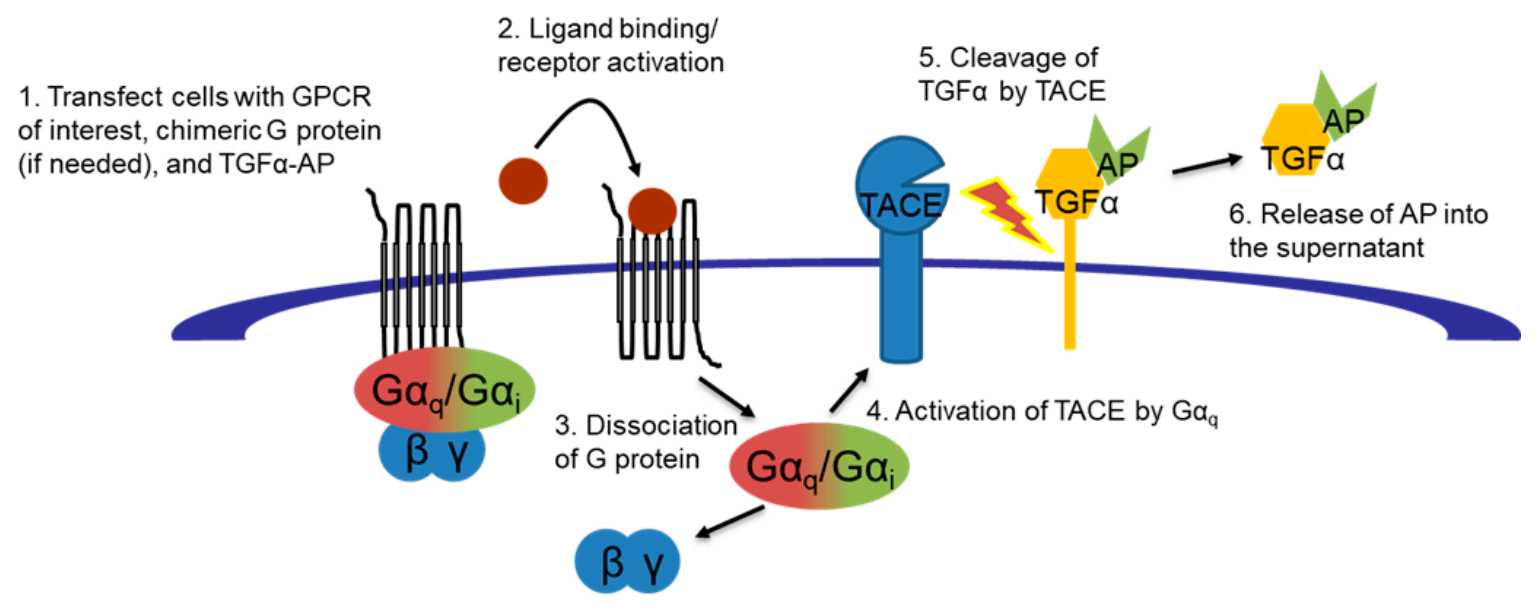

Figure 3. $\mathrm{TGF}_{\alpha}$ shedding assay workflow.

The $\mathrm{TGF}_{\alpha}$ shedding assay results of compounds 3-6 on hA $\mathrm{A}_{3} \mathrm{AR}$ (shown in Figure 4), summarized in Table 1, revealed that the compounds exhibited agonistic activity at the $\mathrm{A}_{3}$ receptor. Compound 4 is the most potent $\mathrm{hA} \mathrm{A}_{3} \mathrm{AR}$ agonist among the four compounds 3-6, with an $\mathrm{EC}_{50}$ of $2.89 \pm 0.55 \mu \mathrm{M}$. It is also a partial $\mathrm{hA}_{3} \mathrm{AR}$ agonist, with an $\mathrm{E}_{\max }$ of $31 \%$, as compared to the efficacy of adenosine. Similarly, compounds 5 and 6 are also weak $\mathrm{hA}_{3} \mathrm{AR}$ agonists, with respective $\mathrm{EC}_{50}$ values of $13.4 \pm 2.96 \mu \mathrm{M}$ and $33.2 \pm 16.50 \mu \mathrm{M}$ but have higher efficacy of $77 \%$ and $72 \%$, respectively. On the other hand, compound 3 is essentially inactive against the $h A_{3} A R$.

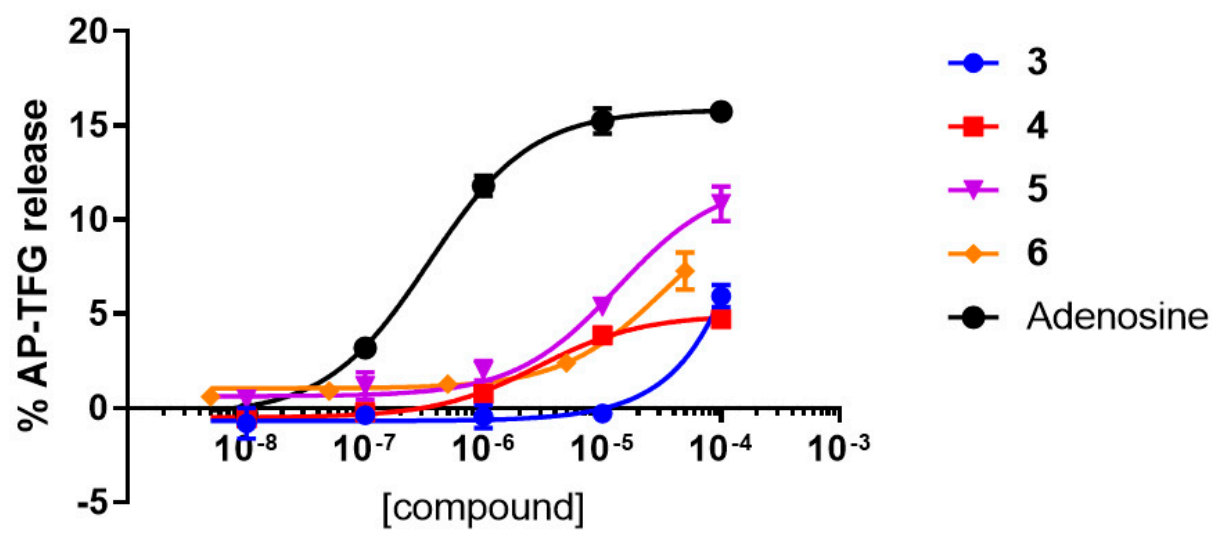

Figure 4. $\mathrm{TGF}_{\alpha}$ shedding assay results at the $\mathrm{hA} \mathrm{A}_{3} \mathrm{AR}$ for compounds 3-6.

Table 1. Potency $\left(\mathrm{EC}_{50}\right)$ and Efficacy $\left(\mathrm{E}_{\max }\right)$ of compounds 3-6 on $\mathrm{hA}_{3} \mathrm{AR}$.

\begin{tabular}{ccc}
\hline Compound & $\mathrm{EC}_{\mathbf{5 0}}(\boldsymbol{\mu M})$ & $\mathrm{E}_{\max }(\mathbf{\%})$ \\
\hline $\mathbf{3}$ & Inactive & N.A. \\
\hline $\mathbf{4}$ & $2.89 \pm 0.55$ & 31 \\
\hline $\mathbf{5}$ & $13.4 \pm 2.96$ & 77 \\
\hline $\mathbf{6}$ & $33.2 \pm 16.50$ & 72 \\
\hline Adenosine & $0.35 \pm 0.03$ & 100 \\
\hline
\end{tabular}

The $\mathrm{TGF}_{\alpha}$ shedding assay at $\mathrm{h} \mathrm{A}_{2 \mathrm{~A}} \mathrm{AR}$ was also performed on the compounds 3-6. Results (Figure 5) showed that compounds 3-6 are all essentially inactive against the human $A_{2 A} A R$, confirming that compounds 4-6 are all human $A_{3} A R$-selective partial agonists with respect to the $h A_{2 A} A R$. 


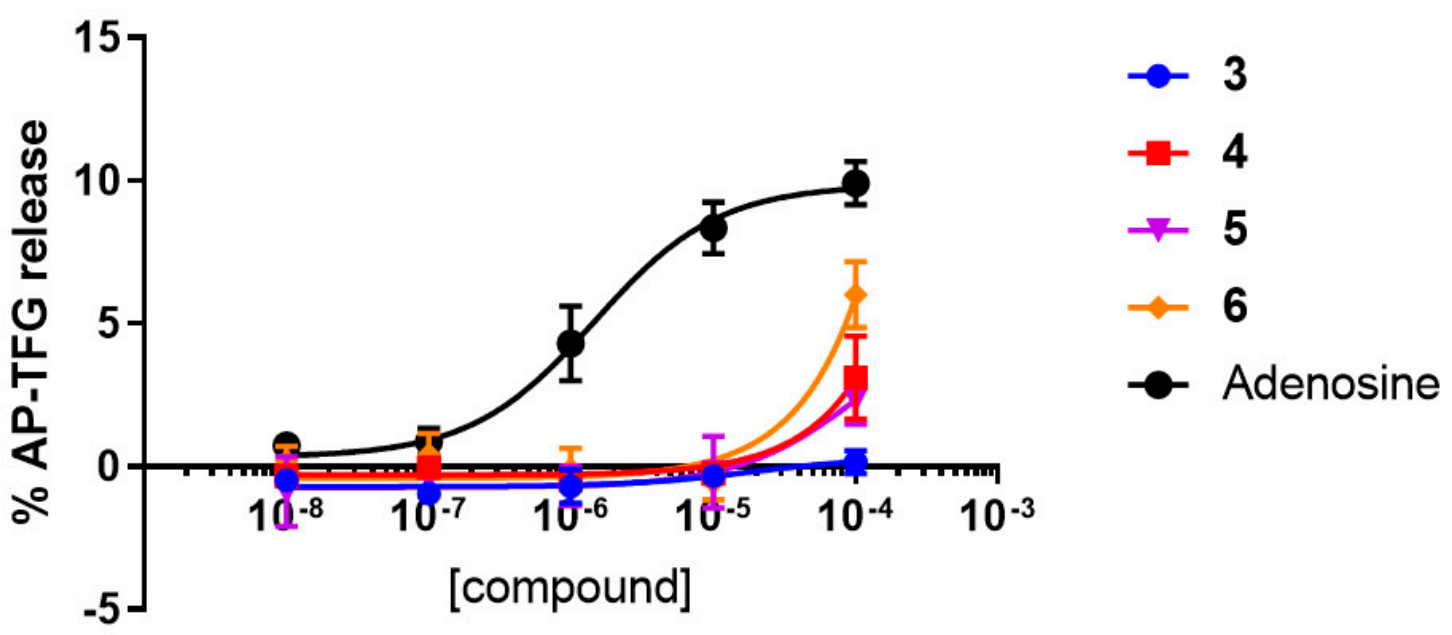

Figure 5. $\mathrm{TGF}_{\alpha}$ shedding assay results at the human $\mathrm{A}_{2 \mathrm{~A}} \mathrm{AR}$ for compounds 3-6.

$\mathrm{TGF}_{\alpha}$ shedding assay results of compounds 3-6 on vector-transfected HEK293 cells, with neither human $\mathrm{A}_{2 \mathrm{~A}} \mathrm{AR}$ nor human $\mathrm{A}_{3} \mathrm{AR}$ expressed (as shown in Figure 6) confirmed that the activity observed in the TGF $\alpha$ shedding assay on $\mathrm{hA}_{3} \mathrm{AR}$-expressing HEK293 cells is due to the action of the compounds on the $\mathrm{hA} \mathrm{A}_{3} \mathrm{AR}$, eliminating eventual external interferences in the HEK293 cells.

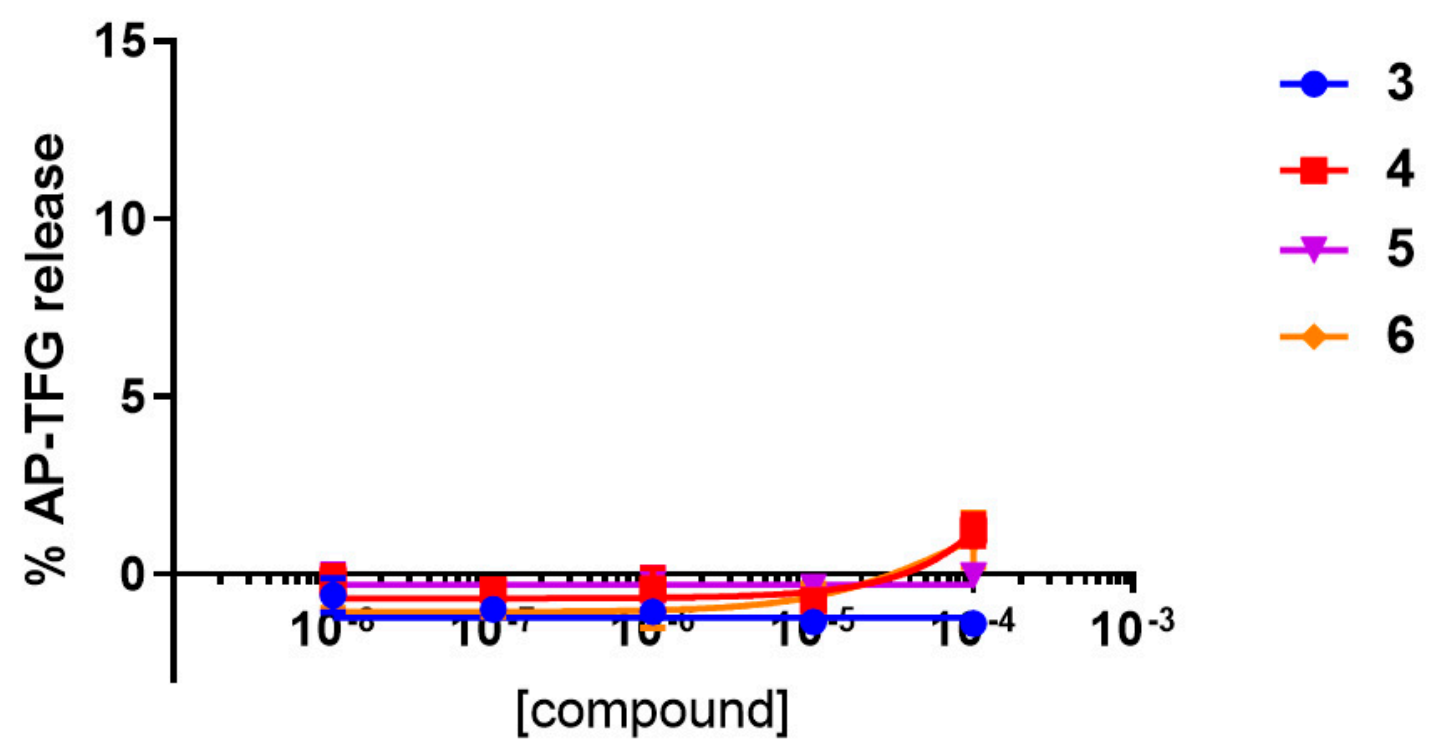

Figure 6. TGF ${ }_{\alpha}$ shedding assay results at the vector-transfected HEK293 cells for compounds 3-6.

The shifting of carbonyl group position in the mIPP scaffold has led to significant reduction of the $\mathrm{hA}_{2 \mathrm{~A}} \mathrm{AR}$ activity, while simultaneously increasing the $\mathrm{h} \mathrm{A}_{3} \mathrm{AR}$ activity and selectivity as $\mathrm{A}_{3}$-selective partial agonists. Of note, previous studies had shown that $h \mathrm{~A}_{3} \mathrm{AR}$-selective full agonists could cause rapid desensitization via $\beta$-arrestin 2 trafficking of the $h A_{3} A R$ upon receptor activation $[23,24]$. Consistently, Bar-Yehuda et al. reported that a reduction in the $\mathrm{hA}_{3} \mathrm{AR}$ expression level was observed in $\mathrm{A}_{3}$ full agonist-treated hepatocellular carcinoma (HCC) tumour-bearing rats as compared to vehicle-treated HCC tumour-bearing rats, indicative of desensitization and reduced expression of $h A_{3} A R$ [25]. In a study by Gao et al., the partial $\mathrm{hA}_{3} \mathrm{AR}$-selective agonist, MRS541, was demonstrated to have a lower $\beta$-arrestin translocation response of $30.8 \pm 1.6 \%$ in comparison to the full $\mathrm{A}_{3} \mathrm{AR}$-selective agonists, IB-MECA and 2-Cl-IB-MECA, which have a high $\beta$-arrestin translocation response of $100 \pm 7 \%$ and $102 \pm 13 \%$, respectively [26]. It can be deduced from these findings that $h \mathrm{~A}_{3} \mathrm{AR}$-selective partial 
agonists would have a lower tendency of triggering rapid receptor trafficking and desensitization of $\mathrm{hA}_{3} \mathrm{AR}$, particularly in cancers that overexpress the $\mathrm{A}_{3}$ receptors.

Among the four compounds, compound 4 was subsequently chosen for further evaluation of its anti-proliferative activity in human colorectal and liver cancer cell lines. This is because it is the most potent among the new mIPP derivatives, with an $\mathrm{EC}_{50}$ of $2.89 \pm 0.55 \mu \mathrm{M}$ at the $\mathrm{hA_{3 }} A \mathrm{AR}$.

\subsubsection{Cytotoxicity Assays of Compound 4 against Human Colorectal Cancer Cell Lines, a Normal} Colon Cell Line and a Liver Cancer Cell Line.

Human colorectal carcinoma cell lines, HCT-116 and Caco-2, were used as models for colorectal cancer cells overexpressing $\mathrm{hA}_{3} \mathrm{AR}$. Human normal colon cell line CCD-18Co was used as a model for normal colon cells that express normal levels of $\mathrm{hA}_{3} \mathrm{AR}$. The HCT-116, Caco-2 and CCD-18Co cell lines were all cultured in accordance with the ATCC protocols.

Cytotoxicity assay results, as shown in Figure 7, indicated that compound 4 is approximately two times more cytotoxic towards the colorectal cancer cell lines, i.e., the HCT-116 cell line $\left(\mathrm{IC}_{50}=84 \pm 9 \mu \mathrm{M}\right)$ and the Caco-2 cell line $\left(\mathrm{IC}_{50}=77 \pm 10 \mu \mathrm{M}\right)$, than the normal colon cell line, the CCD-18Co cell line $\left(\mathrm{IC}_{50}=176 \pm 48 \mu \mathrm{M}\right)$. Hence, compound 4 is cytotoxic-selective for the colorectal cancer cells over its normal counterpart.

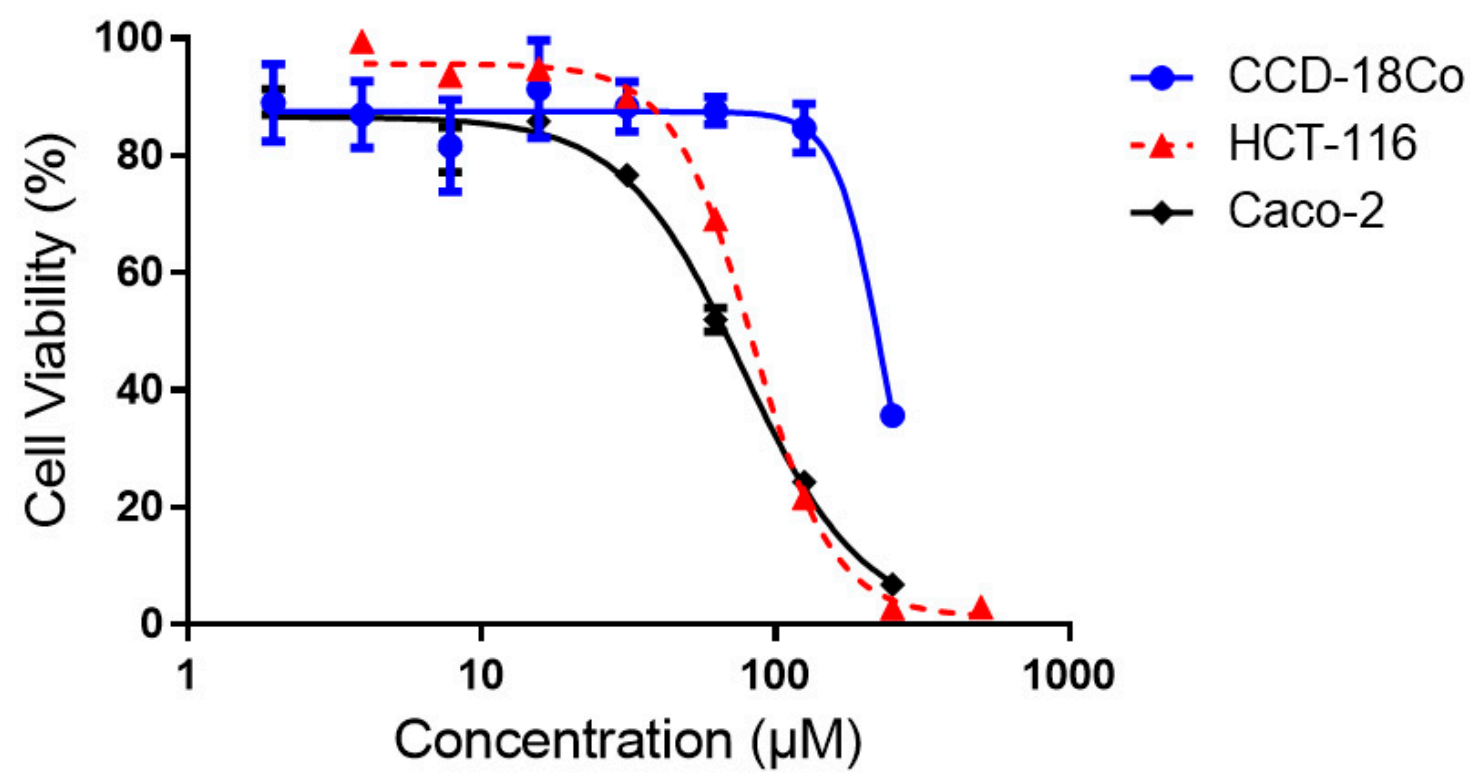

Figure 7. Concentration-effect curves of compound 4 against HCT-116, Caco-2 and CCD-18Co cell lines.

As both healthy and cancerous livers have high expression of $\mathrm{hA}_{3} \mathrm{AR}$, which is remarkably higher than that of colorectal cancer cells, human hepatocellular carcinoma cells (HepG2) were used to test if compound $\mathbf{4}$ is more potent against hepatocellular carcinoma cells versus human colorectal carcinoma cells. The HepG2 cell line was also cultured in accordance with the ATCC protocol.

Based on the results obtained, compound 4 showed higher cytotoxicity against the HepG2 cell line $\left(\mathrm{IC}_{50}=30 \pm 7 \mu \mathrm{M}\right)$ (Table 2), a hepatocellular carcinoma cell line, than against the colorectal cancer cell lines. It also exhibited cytotoxicity of the same order of magnitude to 2-Cl-IB-MECA (Figure 8), a highly potent $h \mathrm{~A}_{3} \mathrm{AR}$-selective agonist. This result suggests that compound 4 , a hA $\mathrm{A}_{3} \mathrm{AR}$-selective partial agonist, can exert the same cytotoxicity as the $\mathrm{hA}_{3} \mathrm{AR}$-selective full agonist, 2-Cl-IB-MECA. This is probably due to the rapid $\mathrm{hA}_{3} \mathrm{AR}$ desensitization upon exposure of the cancer cell lines to the $\mathrm{hA}_{3} \mathrm{AR}$ full agonist, 2-Cl-IB-MECA, as a previous study by Fishman et al. showed significant downregulation of hA $A_{3} \mathrm{AR}$ protein level after only $18 \mathrm{~h}$ of IB-MECA treatment on PC-3 prostate carcinoma cells [27]. Compound 4 might have a lower tendency of causing $h \mathrm{~A}_{3} \mathrm{AR}$ desensitization, which would account for the similar order of magnitude of cytotoxicity as 2-Cl-IB-MECA against the cancer cell lines. However, 
this would need to be further confirmed with a biological study on compound 4 to assess its effect towards $\mathrm{A}_{3} \mathrm{AR}$ trafficking by $\beta$-arrestin.

Table 2. Cytotoxicity assay results of compound 4 and 2-Cl-IB-MECA against HCT-116, Caco-2 and HepG2.

\begin{tabular}{ccc}
\hline & \multicolumn{2}{c}{$\mathrm{IC}_{\mathbf{5 0}}(\boldsymbol{\mu M})$} \\
\cline { 2 - 3 } & $\mathbf{4}$ & 2-Cl-IB-MECA \\
\hline HCT-116 & $84 \pm 9$ & $21 \pm 6$ \\
\hline Caco-2 & $77 \pm 10$ & $31 \pm 4$ \\
\hline HepG2 & $30 \pm 7$ & $13 \pm 3$ \\
\hline
\end{tabular}

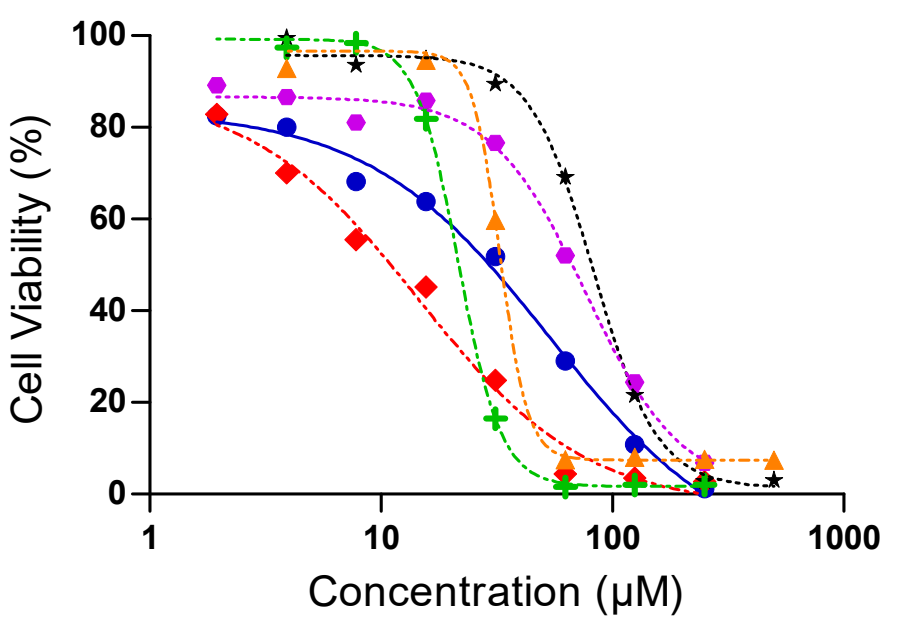

$$
\begin{array}{ll}
-\quad & \text { 7MeOmIPP (HepG2) } \\
\star & \text { 2Cl-IB-MECA (HepG2) } \\
\star & \text { 7MeOmIPP (HCT-116) } \\
+\quad & \text { 2-Cl-IB-MECA (HCT-116) } \\
-\quad & \text { 7MeOmIPP (Caco-2) } \\
\Delta \quad & \text { 2-Cl-IB-MECA (Caco-2) }
\end{array}
$$

Figure 8. Concentration-effect curve of compound 4 and 2-Cl-IB-MECA for cytotoxicity against the gastrointestinal cancer cell lines.

\subsection{UV-Vis Stability Study of Compound 4}

UV-vis stability study of compound 4 showed that it exhibited excellent stability in water, Roswell Park Memorial Institute (RPMI)-1640 culture medium and Dulbecco's Modified Eagle's medium (DMEM) culture medium over $72 \mathrm{~h}$, as indicated by the absence of isosbestic points within the UV-vis spectrum (supplementary information).

\subsection{Induced-Fit Docking of Compound $\mathbf{1}$ and Compounds 3-6 in $h A_{3} A R$ Homology Model}

Induced-fit docking of compound 1 and compounds 3-6 was conducted to rationalize the hA $\mathrm{A}_{3} \mathrm{AR}$ agonistic activity of compounds $3-6$ based on the $h A_{3} A R$ homology model built from the active state $\mathrm{hA}_{2 \mathrm{~A}} \mathrm{AR}$ crystal structure.

As observed in Figure 9A, the induced-fit docking pose for compound 1 indicated a distinct pose compared to that of compounds 4-6. We observed the absence of a crucial hydrogen bonding interaction between the carbonyl group of the amide and Asn $250^{6.55}$ of the $h \mathrm{~A}_{3} \mathrm{AR}$ homology model in compound 1; conversely, the induced-fit docking pose for compound 4 showed the hydrogen bonding interaction between the carbonyl group adjacent to the indole ring and the Asn250 6.55 . This docking result supports our postulation that the shift in position of the carbonyl group from the amide to the position adjacent to the indole ring would confer binding affinity for the $\mathrm{hA}_{3} \mathrm{AR}$, which has been then proven by the gain of $\mathrm{hA}_{3}$ activity in compound 4 .

Generally, the induced-fit docking poses for compounds 3-6 well overlapped with each other in the active site of the $\mathrm{hA}_{3} \mathrm{AR}$ homology model (shown in Figure 9B), adopting similar conformations with the formation of crucial hydrogen bonding interaction between the carbonyl group of the compounds and Asn $250^{6.55}$ as well as the $\pi-\pi$ stacking interaction between the indolyl ring of the compounds and Phe168. 
In particular, an interesting observation was made from the induced-fit docking results of compounds 3-6. The Trp243 $3^{6.48}$ was found to adopt a different degree of rotation for compounds 4-6 as compared to that of compound 3 (shown in Figure 9C). Previous molecular modelling studies with a $h A_{3} A R$ homology model built from the $\mathrm{hA}_{2 \mathrm{~A}} \mathrm{AR}$ crystal structure also reported similar observation of rotation of the Trp $243^{6.48}$ residue from its inactive "vertical" conformation to the active "horizontal" conformation upon agonist binding [28-31]. In fact, a site-directed mutagenesis study reported in Gao et al. demonstrated that $\operatorname{Trp} 243^{6.48}$ is a residue crucial for the $A_{3}$ receptor activation [32-34]. This residue might act as a switch in TM6-mediated structural transition from the resting to the active state of the $\mathrm{A}_{3}$ receptor upon binding of agonist. The difference in rotation of Trp243 residue observed between compound 3 and compounds $\mathbf{4} \mathbf{- 6}$ is in concordance with our findings from the TGF $\alpha$ shedding assay, whereby compound 3 was found to be inactive against $h \mathrm{~A}_{3} \mathrm{AR}$, while compounds $4-6$ showed relatively higher $\mathrm{hA}_{3} \mathrm{AR}$ agonistic activity.
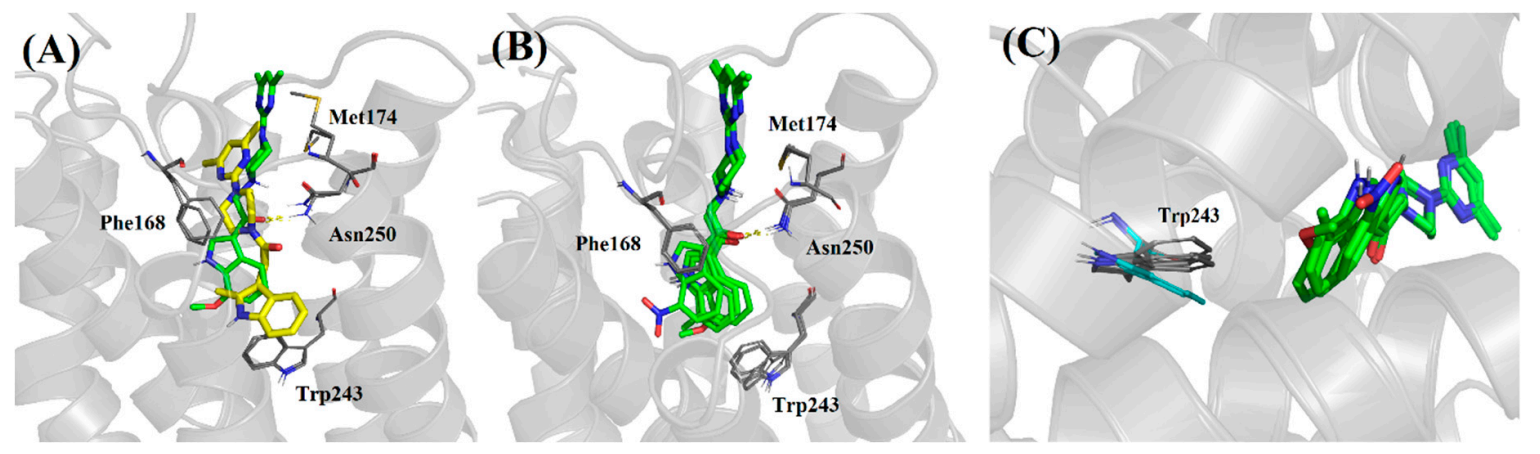

Figure 9. (A) Overlapping docking poses of compound 1 (yellow) and compound 4 (green) in the $\mathrm{hA}_{3} \mathrm{AR}$ homology model. (B) Overlapping docking poses of compounds $3-6$ in the hA 3 AR homology model. (C) Rotation of Trp $243^{6.48}$ observed in induced-fit docking of 4, 5 and 6 (grey), absent in 3 (blue).

\section{Materials and Methods}

\subsection{Chemistry}

General ${ }^{1} \mathrm{H}$ and ${ }^{13} \mathrm{C}$ nuclear magnetic resonance (NMR) spectra (DMSO- $\mathrm{d}_{6}$ ) were recorded on a Bruker DPX Ultrashield NMR $(400 \mathrm{MHz})$. Chemical shifts are reported as parts per million $(\delta)$ relative to the solvent peak. Coupling constants $(J)$ are reported in hertz $(\mathrm{Hz})$. High Performance Liquid Chromatography (HPLC) analysis was conducted with Agilent HP-1100 system equipped with a diode array detector (DAD). Reactions were checked with thin layer chromatography (TLC) (Merck precoated $60 \mathrm{~F}_{254}$ plates). Flash chromatography was performed on silica gel 60 (70-230 mesh, Merck). Unless otherwise stated, materials were obtained from commercial suppliers and used without further purification. All anhydrous and technical-grade solvents were also obtained from commercial suppliers and used without further purification or drying.

2-Chloro-1-(1H-indol-3-yl)ethanone (7): Pyridine (1 equiv.) was added to a solution of indole (1 equiv.) in $20 \mathrm{~mL}$ of dry dioxane under argon and the mixture was warmed to $60{ }^{\circ} \mathrm{C}$. Chloroacetyl chloride (1 equiv.) was added dropwise over $10 \mathrm{~min}$ and the reaction mixture was allowed to stir at $60^{\circ} \mathrm{C}$ for $1 \mathrm{~h}$. The reaction mixture was poured into $40 \mathrm{~mL}$ of iced water and extracted with $40 \mathrm{~mL}$ of ethyl acetate (EA) twice. The organic layer was washed with brine before drying with anhydrous sodium sulphate. The mixture was concentrated in vacuo and crudes were dry-loaded onto silica gel and purified with column chromatography (EA: Hexane $=1: 100$ to 1:4) to give the desired product, 3-chloroacetylindole as a brownish solid in 50\% yield. ${ }^{1} \mathrm{H}$ NMR $\left(400 \mathrm{MHz}, \mathrm{DMSO}-\mathrm{d}_{6}\right): \delta=12.12(\mathrm{~s}, 1 \mathrm{H}), 8.43(\mathrm{~d}, J=3.24 \mathrm{~Hz}$, $1 \mathrm{H}), 8.17-8.15(\mathrm{~m}, 1 \mathrm{H}), 7.51-7.49(\mathrm{~m}, 1 \mathrm{H}), 7.27-7.23(\mathrm{~m}, 1 \mathrm{H}), 7.23-7.20(\mathrm{~m}, 1 \mathrm{H}), 4.87$ (s, $2 \mathrm{H}) .{ }^{13} \mathrm{C}$ NMR $\left.(\text { DMSO-d })_{6}\right): \delta=186.16,136.61,134.75,125.39,123.19,122.15,121.15,113.61,112.33,46.38$. 
4,6-Dimethyl-2-(piperazin-1-yl)pyrimidine (8): To a stirred solution of piperazine (5 equiv.) and potassium carbonate (5 equiv.) in $24 \mathrm{~mL}$ of deionized water, 2-chloro-4,6-dimethylpyrimidine (1 equiv.) in $6 \mathrm{~mL}$ of tetrahydrofuran was added. The reaction mixture was stirred at room temperature for $24 \mathrm{~h}$. After $24 \mathrm{~h}$, tetrahydrofuran was evaporated in vacuo and the aqueous layer was extracted with $25 \mathrm{~mL}$ of EA three times. The combined organic layer was dried with anhydrous sodium sulphate and dry-loaded onto silica gel. Crudes dry-loaded on silica gel were purified by flash chromatography (EA: Hexane $=1: 100-100: 1)$ to give 4,6-dimethyl-2-(piperazin-1-yl)pyrimidine as a white solid in $96 \%$ yield. ${ }^{1} \mathrm{H}$ NMR $\left(400 \mathrm{MHz}\right.$, DMSO-d $\left.{ }_{6}\right): \delta=6.35(\mathrm{~s}, 1 \mathrm{H}), 3.63(\mathrm{t}, J=5.00 \mathrm{~Hz}, 4 \mathrm{H}), 2.69(\mathrm{t}, J=4.88 \mathrm{~Hz}, 4 \mathrm{H})$, $2.20(\mathrm{~s}, 6 \mathrm{H}) .{ }^{13} \mathrm{C}$ NMR $\left(\right.$ DMSO-d $\left._{6}\right): \delta=166.47,161.28,108.37,45.55,44.46,23.69$.

General procedure for direct acylation to obtain 7-methoxy and 7-chloro substituted 3-chloroacetylindole (9-10). 7-substituted indoles (1 equiv.) was weighed in a microwave vial and the microwave vial was capped after adding the stir bar before purging with argon. $5 \mathrm{~mL}$ of dichloroethane (DCE) was added to the microwave vial to dissolve the 7-substituted indoles. DBU (1 equiv.) was added to the reaction mixture and heated in an oil bath to $90^{\circ} \mathrm{C}$. Upon reaching $90^{\circ} \mathrm{C}$, chloroacetyl chloride (1.1 equiv.) was added in a single portion into the microwave vial via syringe. The reaction was stirred and monitored with TLC hourly until product spot was observed and qualitative yield was obtained, before heating was stopped. The reaction mixture upon cooling was added to a water-methanol mixture of 6:1 under vigorous stirring to quench the reaction. The quenched reaction was allowed to stir for an additional $1 \mathrm{~h}$ and solid crude product was filtered with a sintered glass filter funnel before washing with water. The crude product was allowed to dry in an oven before dissolving in methanol. The dissolved crude product was dry loaded onto silica gel and was purified with column chromatography (EA: Hexane = 1:100-1:4) to give the pure 7-substituted 3-chloroacetylindole.

2-Chloro-1-(7-methoxy-1H-indol-3-yl)ethanone (9): Brownish solid, yield: 23\%. ${ }^{1} \mathrm{H}$ NMR (400 MHz, DMSO- $\left.\mathrm{d}_{6}\right): \delta=12.27(\mathrm{~s}, 1 \mathrm{H}), 8.32(\mathrm{~d}, J=3.28 \mathrm{~Hz}, 1 \mathrm{H}), 7.74-7.72(\mathrm{~d}, J=7.92 \mathrm{~Hz}, 1 \mathrm{H}), 7.14(\mathrm{t}, J=7.92 \mathrm{~Hz}$, $1 \mathrm{H}), 6.82(\mathrm{~d}, J=7.44 \mathrm{~Hz}, 1 \mathrm{H}), 4.88(\mathrm{~s}, 2 \mathrm{H}), 3.94(\mathrm{~s}, 3 \mathrm{H}) .{ }^{13} \mathrm{C}$ NMR $\left(\right.$ DMSO-d $\left._{6}\right): \delta=186.20,146.27$, $133.96,126.94,126.59,122.95,114.10,113.64,103.86,55.32,46.48$.

2-Chloro-1-(7-chloro-1H-indol-3-yl)ethanone (10): Yellowish solid, yield: $11 \% .{ }^{1} \mathrm{H}$ NMR $(400 \mathrm{MHz}$, DMSO- $\left.\mathrm{d}_{6}\right): \delta=12.50(\mathrm{~s}, 1 \mathrm{H}), 8.52-8.51(\mathrm{~d}, J=3.24 \mathrm{~Hz}, 1 \mathrm{H}), 8.13-8.11(\mathrm{~d}, J=7.88 \mathrm{~Hz}, 1 \mathrm{H}), 7.36-7.33$ $(\mathrm{dd}, J=7.64 \mathrm{~Hz}, 0.68 \mathrm{~Hz}, 1 \mathrm{H}), 7.23(\mathrm{t}, J=7.80 \mathrm{~Hz}, 1 \mathrm{H}), 4.94(\mathrm{~s}, 2 \mathrm{H}) .{ }^{13} \mathrm{C}$ NMR $\left(\mathrm{DMSO}-\mathrm{d}_{6}\right): \delta=186.42$, $135.55,133.52,127.27,123.29,122.79,120.09,116.62,114.43,46.54$.

Procedure for Vilsmeier-Haack acylation to obtain 7-nitro substituted 3-chloroacetylindole (12). Chloroacetyl chloride ( 3 equiv.) was added dropwise to a stirring mixture of dimethylamine hydrochloride (1 equiv.) and triethylamine (1.1 equiv.) in an ice bath. The reaction was allowed to stir further in the ice bath for $3 \mathrm{~h}$ before $40 \mathrm{~mL}$ of water was added for quenching the reaction. The aqueous layer was extracted with $50 \mathrm{~mL}$ of dichloromethane (DCM) twice and the combined organic layer was washed three times with $50 \mathrm{~mL}$ of $1 \mathrm{M}$ hydrochloric acid. The organic layer was concentrated in vacuo before being dispersed in diethyl ether and stirred overnight. Solid precipitate was filtered away and the organic layer was reconcentrated in vacuo to afford the purified 2-chloro- $N, N$-dimethylacetamide (11) as a liquid.

7-nitroindole (1 equiv.) was dissolved in a neat solution of $\mathbf{1 1}$ (5 equiv.). The mixture was stirred under argon in an ice bath. Phosphorus oxychloride (2 equiv.) was added dropwise into the reaction mixture in the ice bath. The reaction mixture was allowed to stir overnight at room temperature. The reaction was neutralized with $4 \mathrm{~mL}$ of $2 \mathrm{M}$ aqueous sodium hydroxide solution. The aqueous layer was extracted with $10 \mathrm{~mL}$ of EA three times. Combined organic layers were washed with $30 \mathrm{~mL}$ saturated sodium bicarbonate twice. The organic layer was dried over anhydrous sodium sulphate and concentrated in vacuo. Residue obtained was purified with column chromatography (EA: Hexane $=1: 100-1: 4$ ) to give pure 2-chloro-1-(7-nitro-1H-indol-3-yl)ethanone (12). 
2-Chloro- $N, N$-dimethylacetamide (11): Dark brownish liquid, yield: $62 \% .{ }^{1} \mathrm{H} \mathrm{NMR}\left(400 \mathrm{MHz}, \mathrm{CDCl}_{3}\right)$ : $\delta=3.86(\mathrm{~s}, 1 \mathrm{H}), 2.81(\mathrm{~s}, 3 \mathrm{H}), 2.67(\mathrm{~s}, 3 \mathrm{H}) .{ }^{13} \mathrm{C} \mathrm{NMR}\left(\mathrm{CDCl}_{3}\right): \delta=166.06,40.84,36.92,35.31$.

2-Chloro-1-(7-nitro-1H-indol-3-yl)ethanone (12): Brownish solid, yield: 17\%. ${ }^{1} \mathrm{H}$ NMR (400 MHz, DMSO-d $\left._{6}\right): \delta=12.73(\mathrm{~s}, 1 \mathrm{H}), 8.64-8.62(\mathrm{dd}, J=7.84 \mathrm{~Hz}, 0.92 \mathrm{~Hz}, 1 \mathrm{H}), 8.57(\mathrm{~d}, J=2.08 \mathrm{~Hz}, 1 \mathrm{H})$, 8.24-8.21 (dd, $J=8.04 \mathrm{~Hz}, 0.90 \mathrm{~Hz}, 1 \mathrm{H}), 7.47(\mathrm{t}, J=7.96 \mathrm{~Hz}, 1 \mathrm{H}), 5.02(\mathrm{~s}, 2 \mathrm{H}) .{ }^{13} \mathrm{C}$ NMR $\left(\mathrm{DMSO}_{6}\right)$ : $\delta=186.91,137.11,133.39,129.35,129.08,128.82,122.20,120.18,114.26,46.80$.

General procedure for synthesis of mIPP and its derivatives (3-6). Chloroacetylindole (1 equiv.) was added to a stirred mixture of 4,6-dimethyl-2-(piperazin-1-yl)pyrimidine (1 equiv.), potassium carbonate (3 equiv.) and sodium iodide (1 equiv.) in $60 \mathrm{~mL}$ of acetonitrile. The reaction mixture was stirred under reflux for $4 \mathrm{~h}$. Upon completion of the reaction determined by TLC analysis, the reaction mixture was cooled to room temperature and acetonitrile was removed in vacuo to give a dry residue. The dry residue was washed with water to remove the salts and the precipitate was dissolved in methanol and dry-loaded onto silica gel. Crude dry-loaded on silica gel were purified by column chromatography (EA: Hexane $=1: 100-3: 1$ ) to give mIPP and its derivatives.

2-(4-(4,6-Dimethylpyrimidin-2-yl)piperazin-1-yl)-1-(1H-indol-3-yl)ethanone (3): White solid, yield: $38 \%, \mathrm{mp}=165{ }^{\circ} \mathrm{C}$ (decomp): ${ }^{1} \mathrm{H}$ NMR $\left(400 \mathrm{MHz}, \mathrm{DMSO}_{6} \mathrm{~d}_{6}\right) \delta 11.91(\mathrm{~s}, 1 \mathrm{H}), 8.49(\mathrm{~s}, 1 \mathrm{H}), 8.20-8.18(\mathrm{~m}$, $1 \mathrm{H}), 7.48-7.46(\mathrm{~m}, 1 \mathrm{H}), 7.23-7.20(\mathrm{~m}, 1 \mathrm{H}), 7.19-7.16(\mathrm{~m}, 1 \mathrm{H}), 6.40(\mathrm{~s}, 1 \mathrm{H}), 3.76-3.74(\mathrm{~m}, 4 \mathrm{H}), 3.66(\mathrm{~s}, 2 \mathrm{H})$, 2.59-2.57 (m, 4H), $2.22(\mathrm{~s}, 6 \mathrm{H}) .{ }^{13} \mathrm{C}$ NMR $\left(\mathrm{DMSO}_{\mathrm{d}}\right.$ ) $) \delta=192.37,166.63,161.17,136.28,134.19,125.60$, $122.74,121.72,121.32,115.23,112.07,108.72,64.99,52.79,43.31,23.69$. HPLC analysis of compound purity by two solvent systems: $\mathrm{ACN}: \mathrm{H}_{2} \mathrm{O}=70: 30(98 \%), \mathrm{MeOH}: \mathrm{H}_{2} \mathrm{O}=70: 30(99 \%)$.

2-(4-(4,6-Dimethylpyrimidin-2-yl)piperazin-1-yl)-1-(7-methoxy-1H-indol-3-yl)ethanone (4): White solid, yield: $77 \%, \mathrm{mp}=162{ }^{\circ} \mathrm{C}($ decomp $):{ }^{1} \mathrm{H}$ NMR $\left(400 \mathrm{MHz}, \mathrm{DMSO}_{\mathrm{d}}\right) \delta 12.05(\mathrm{~s}, 1 \mathrm{H}), 8.36(\mathrm{~d}, J=3.16 \mathrm{~Hz}$, $1 \mathrm{H}), 7.76(\mathrm{~d}, J=7.96 \mathrm{~Hz}, 1 \mathrm{H}), 7.12-7.08(\mathrm{~m}, 1 \mathrm{H}), 6.80-6.78(\mathrm{~m}, 1 \mathrm{H}), 6.39(\mathrm{~s}, 1 \mathrm{H}), 3.93(\mathrm{~s}, 3 \mathrm{H}), 3.74-3.72(\mathrm{~m}$, $4 \mathrm{H}), 3.64(\mathrm{~s}, 2 \mathrm{H}), 2.58-2.55(\mathrm{~m}, 4 \mathrm{H}), 2.21(\mathrm{~s}, 6 \mathrm{H}) .{ }^{13} \mathrm{C} \mathrm{NMR}\left(\mathrm{DMSO}_{6}\right): \delta=192.43,166.64,161.17,146.20$, 133.40, 127.16, 126.28, 122.53, 115.74, 113.91, 108.73, 103.49, 65.01, 55.29, 52.75, 43.30, 23.68. HPLC analysis of compound purity by two solvent systems: $\mathrm{ACN}: \mathrm{H}_{2} \mathrm{O}=70: 30(95 \%), \mathrm{MeOH}: \mathrm{H}_{2} \mathrm{O}=70: 30$ (95\%).

2-(4-(4,6-Dimethylpyrimidin-2-yl)piperazin-1-yl)-1-(7-chloro-1H-indol-3-yl)ethanone (5): White solid, yield: $59 \%, \mathrm{mp}=163{ }^{\circ} \mathrm{C}(\mathrm{decomp}):{ }^{1} \mathrm{H}$ NMR $\left(400 \mathrm{MHz}, \mathrm{DMSO}_{6} \mathrm{~d}_{6}\right) \delta 12.31(\mathrm{~s}, 1 \mathrm{H}), 8.56(\mathrm{~d}, J=2.84 \mathrm{~Hz}$, $1 \mathrm{H}), 8.17-8.15(\mathrm{~m}, 1 \mathrm{H}), 7.32-7.30(\mathrm{dd}, J=7.60 \mathrm{~Hz}, 0.86 \mathrm{~Hz}, 1 \mathrm{H}), 7.20(\mathrm{t}, J=7.84 \mathrm{~Hz}, 1 \mathrm{H}), 6.39(\mathrm{~s}, 1 \mathrm{H})$, 3.75-3.72 (m, 4H), $3.69(\mathrm{~s}, 2 \mathrm{H}), 2.59-2.56(\mathrm{~m}, 4 \mathrm{H}), 2.22(\mathrm{~s}, 6 \mathrm{H}){ }^{13}{ }^{3} \mathrm{C}$ NMR $\left(\right.$ DMSO-d $\left._{6}\right): \delta=192.62,166.61$, $161.13,134.99,133.17,127.51,122.88,122.36,120.27,116.43,115.97,108.72,64.97,52.72,43.28,23.68$. HPLC analysis of compound purity by two solvent systems: $\mathrm{ACN}: \mathrm{H}_{2} \mathrm{O}=70: 30(89 \%), \mathrm{MeOH}: \mathrm{H}_{2} \mathrm{O}=$ 70:30 (89\%). Purification by prep-HPLC was conducted to obtain just the desired product (98\% purity).

2-(4-(4,6-Dimethylpyrimidin-2-yl)piperazin-1-yl)-1-(7-nitro-1H-indol-3-yl)ethanone (6): White solid, yield: $69 \%, \mathrm{mp}=165^{\circ} \mathrm{C}\left(\right.$ decomp): ${ }^{1} \mathrm{H}$ NMR $\left(400 \mathrm{MHz}, \mathrm{DMSO}_{\mathrm{d}}\right) \delta 12.56(\mathrm{~s}, 1 \mathrm{H}), 8.68(\mathrm{~d}, J=7.36 \mathrm{~Hz}$, $0.92 \mathrm{~Hz}, 1 \mathrm{H}), 8.65(\mathrm{~d}, J=3.00 \mathrm{~Hz}, 1 \mathrm{H}), 8.21(\mathrm{dd}, J=8.04 \mathrm{~Hz}, 0.90 \mathrm{~Hz} 1 \mathrm{H}), 7.47-7.43(\mathrm{t}, J=7.96 \mathrm{~Hz}, 1 \mathrm{H})$, $6.40(\mathrm{~s}, 1 \mathrm{H}), 3.78(\mathrm{~s}, 2 \mathrm{H}), 3.76(\mathrm{dd}, J=4.84 \mathrm{~Hz}, 0.42 \mathrm{~Hz}, 4 \mathrm{H}), 2.61-2.59(\mathrm{~m}, 4 \mathrm{H}), 2.22(\mathrm{~s}, 6 \mathrm{H}) .{ }^{13} \mathrm{C} \mathrm{NMR}$ $\left(\right.$ DMSO $\left.\mathrm{d}_{6}\right): \delta=166.64,161.12,136.62,133.21,129.53,129.33,128.45,121.78,119.80,115.61,108.78$, $65.06,52.68,43.20,23.68$. HPLC analysis of compound purity by two solvent systems: $\mathrm{ACN}: \mathrm{H}_{2} \mathrm{O}=$ 70:30 (95\%), $\mathrm{MeOH}: \mathrm{H}_{2} \mathrm{O}=70: 30$ (95\%).

\subsection{Biological Evaluation}

\subsection{1. $\mathrm{TGF}_{\alpha}$ Shedding Assays for $\mathrm{hA}_{2 \mathrm{~A}} \mathrm{AR}$ and $\mathrm{hA_{3 }} \mathrm{AR}$}

Expression vectors (250 $\mathrm{ng}$ of $\mathrm{AP}-\mathrm{TGF}_{\alpha}$ plasmid, $100 \mathrm{ng}$ of $\mathrm{hA}_{2 \mathrm{~A}} \mathrm{AR} / \mathrm{h} \mathrm{A}_{3} \mathrm{AR}$ plasmid and $50 \mathrm{ng}$ of $\mathrm{G}_{\alpha}$ protein) were transfected into HEK293 cells using Lipofectamine $2000(1.25 \mu \mathrm{L} /$ well $)$ in 12-well plates. Transfection of siRNA (final concentration: $10 \mathrm{nM}$ ) was conducted with Lipofectamine RNAiMAX 
( $1 \mu \mathrm{L} /$ well), $48 \mathrm{~h}$ before assay to prevent interference from other signaling pathways. Transfected cells were detached with brief treatment with phosphate-buffered saline (PBS) containing $0.05 \%$ trypsin and $0.52 \mathrm{mM}$ ethylenediaminetetraacetic acid (EDTA). The cell suspension was pelleted via centrifugation $(190 \mathrm{~g}, 5 \mathrm{~min})$. Trypsin was removed from the cells via resuspension in PBS, followed by $5 \mathrm{~min}$ of incubation at room temperature. Cells were subsequently pelleted with centrifugation $(190 \mathrm{~g}, 5 \mathrm{~min})$ and resuspended in Hank's Balanced Salt Solution (HBSS) containing $5 \mathrm{mM}$ 4-(2-hydroxyethyl)-1-piperazineethanesulfonic acid (HEPES) (pH 7.4). Resuspended cells were plated in $90 \mu \mathrm{L} /$ well in 96-well plate and incubated at $37^{\circ} \mathrm{C}$ in $5 \% \mathrm{CO}_{2}$ for $30 \mathrm{~min} .10 \mu \mathrm{L}$ of $10 \mathrm{X}$ concentration of compounds were added and incubated for $1 \mathrm{~h}$ at $37^{\circ} \mathrm{C}$ in $5 \% \mathrm{CO}_{2}$. Plates were centrifuged at $190 \mathrm{~g}$ for $2 \mathrm{~min} .160 \mu \mathrm{L}$ per well of conditioned medium (10 mM p-NPP, $40 \mathrm{mM}$ Tris- $\mathrm{HCl}$ (pH 9.5), $40 \mathrm{mM} \mathrm{NaCl} \& 10 \mathrm{mM} \mathrm{MgCl}$ ) was transferred into a conditioned medium plate and $80 \mu \mathrm{L}$ per well of conditioned medium was added to the test compound plate. Absorbance at $405 \mathrm{~nm}(\mathrm{OD} 405)$ of both plates was read before and after a 1-h incubation at $37^{\circ} \mathrm{C}$ using a microplate reader [22].

\subsubsection{Cytotoxicity Assays}

The cytotoxicity of compound 4 was determined by 3-(4,5-dimethylthiazol-2-yl)-2,5diphenyltetrazolium bromide (MTT) assay. The cells were harvested from culture flasks by trypsinisation and seeded into 96-well microculture plates (Costar, Corning, USA) at the seeding density of 6000 cells per well or 10,000 per well (CCD18Co). After the cells were allowed to resume exponential growth for $24 \mathrm{~h}$, they were exposed to compound 4 or 2-Cl-IB-MECA in media for $72 \mathrm{~h}$. The drugs were diluted in complete medium at the desired concentration, and $100 \mu \mathrm{L}$ of the drug solution was added to each well and serially diluted to other wells. After exposure for $72 \mathrm{~h}$, drug solutions were replaced with $100 \mu \mathrm{L}$ of MTT in complete media $\left(5 \mathrm{mg} \mathrm{ml}^{-1}\right)$ and incubated for an additional $1 \mathrm{~h}$. Subsequently, the medium was aspirated and the purple formazan crystals formed in viable cells were dissolved in $100 \mu \mathrm{L}$ of dimethyl sulfoxide (DMSO) per well. Optical densities were measured at $570 \mathrm{~nm}$ with a microplate reader. The quantity of viable cells was expressed in terms of treated/control (T/C) values by comparison to untreated control cells, and $50 \%$ inhibitory concentrations $\left(\mathrm{IC}_{50}\right)$ were calculated from concentration-effect curves by interpolation using GraphPad Prism (Version 5.0, GraphPad Software, USA). Evaluation was based on means from at least three independent experiments, each comprising six replicates per concentration level.

\subsection{UV-Vis Stability Assay}

Stock solution of $50 \mu \mathrm{M}$ of compound 4 was prepared in DMSO. Two quartz cuvettes were soaked in $70 \%$ ethanol in water for $1 \mathrm{~h}$. The quartz cuvettes were subsequently left to dry in a biological safety cabinet. When both quartz cuvettes were dry, the quartz cuvettes, i.e., sample cuvette and blank cuvette, were filled with water or culture media (RPMI-1640 or DMEM) and parafilmed before being transferred into a UV-vis spectrophotometer (USA). The UV-vis spectrophotometer was auto-zeroed and the background was scanned from wavelengths of $200 \mathrm{~nm}$ to $800 \mathrm{~nm}$. The sample cuvette was removed from the UV-vis spectrophotometer and transferred into the biological safety cabinet. Compound 4 was dissolved at a final concentration of $50 \mu \mathrm{M}$ in $1.5 \mathrm{~mL}$ of water, RPMI or DMEM containing $10 \%$ FBS (without phenol red). The UV-vis profiles of the samples were monitored using UV-vis over $72 \mathrm{~h}$ at $1 \mathrm{~h}$ intervals from 200 to $800 \mathrm{~nm}$.

\subsection{Molecular Modeling}

\subsubsection{Homology Modelling and Protein Preparation}

The amino acid sequence of $h \mathrm{~A}_{3} \mathrm{AR}$ was obtained from the UniProt Knowledgebase (P0DMS8) and was aligned to $\mathrm{hA}_{2 \mathrm{~A}} \mathrm{AR}$ using the structural alignment specified in GPCRdb [35]. The N-terminal and C-terminal were truncated (residues 1-8 and 305-318). The $\mathrm{hA}_{3} \mathrm{AR}$ homology model was then constructed using Prime [36], based on the crystal structure of the active-state $h \mathrm{~A}_{2 \mathrm{~A}} \mathrm{AR}$ bound to the 
selective agonist UK-432,097 as a template (PDB ID: 3QAK) [37]. The disulphide bridge between Cys $83^{3.25}$ and Cys $166^{45.50}$ in hA $\mathrm{A}_{3} \mathrm{AR}$ was conserved. The stereochemical quality of the $\mathrm{h} \mathrm{A}_{3} \mathrm{AR}$ homology model was assessed using PROCHECK [38] (supplementary information). The homology model was subsequently prepared for docking by assigning appropriate protonation states, which were generated at $\mathrm{pH}$ 7.4, and by optimizing the hydrogen bond networks. The resulting structure was subjected to energy minimization by using the OPLS 2005 force field.

\subsubsection{Ligand Docking Studies}

In-depth computational studies were conducted with Schrödinger Maestro using induced-fit docking protocol. Ligands were prepared for docking via LigPrep [39]. Ligand protonation states were generated at pH 7.4 using Epik [40]. The docking was then performed using the Induced Fit Docking protocol, with the docking grid centred on the $\mathrm{hA}_{3} \mathrm{AR}$ active site [41].

\section{Conclusions}

The present work confirmed our postulation that the structural modification of the IPP scaffold through shifting of the carbonyl group to the position adjacent to the indole ring would diminish the $A_{2 A}$ activity while gaining activity at the $A_{3}$ receptor. Among these newly synthesized mIPP derivatives, compound 4 was shown as a $\mathrm{hA}_{3} \mathrm{AR}$-selective partial agonist with an $\mathrm{EC}_{50}$ of $2.89 \pm 0.55 \mu \mathrm{M}$ and $\mathrm{E}_{\max }$ of $30 \%$ that exhibited some extent of selectivity for cancer cells over normal cells. Furthermore, the molecular modelling studies suggest that the difference in rotation of Trp243 residue might account for dissimilarity in agonistic activity observed among the new MIPP derivatives, indicating its role in $\mathrm{A}_{3}$ receptor activation. Further structural optimizations of compound 4 would be deemed useful in developing more potent $\mathrm{h} \mathrm{A}_{3} \mathrm{AR}$-selective partial agonists in the future.

In addition, relevant biological studies can be conducted to determine if the $\mathrm{hA}_{3} \mathrm{AR}$ partial agonist possesses a reduced tendency of causing desensitization of the $\mathrm{hA}_{3} \mathrm{AR}$ in cancer cells and reduced non-selective actions towards normal liver tissues that are intrinsically expressing high levels of $\mathrm{hA}_{3} \mathrm{AR}$.

Supplementary Materials: The following are available online, Figure S1: ${ }^{1} \mathrm{H}$ NMR of Compound 3., Figure S2: ${ }^{13} \mathrm{C}$ NMR of Compound 3. Figure S3: ${ }^{1} \mathrm{H}$ NMR of Compound 4., Figure S4: ${ }^{13} \mathrm{C}$ NMR of Compound 4., Figure S5: ${ }^{1} \mathrm{H}$ NMR of Compound 5., Figure S6: ${ }^{13} \mathrm{C}$ NMR of Compound 5., Figure S7: ${ }^{1} \mathrm{H}$ NMR of Compound 6., Figure S8: ${ }^{13} \mathrm{C}$ NMR of Compound 6., Figure S9: UV-stability of Compound 4 in water over 72h., Figure S10: UV-stability of Compound 4 in DMEM over 72h., Figure S11: UV-stability of Compound 4 in RPMI-1640 over 72h. Figure S12: Ramachandran plot for $\mathrm{hA}_{3} \mathrm{AR}$ homology model (PROCHECK analysis).

Author Contributions: Conceptualization: A.T., G.S., G.P.; data curation: A.T., M.V.B., C.L., D.R.H., K.-N.K., J.S.E.L., G.P.; formal analysis: A.T., M.V.B., C.L., G.V., D.R.H., K.-N.K., J.S.E.L., G.P.; funding acquisition: G.P.; investigation: A.T., J.S.E.L., S.L.C., S.F.; methodology: A.T., D.R.H., K.-N.K., Y.Z.C., G.P.; project administration: S.F., G.S., S.L.C., G.P.; resources: G.P., W.-Y.O.; supervision: J.S.E.L., S.L.C., D.R.H., K.-N.K., W.-Y.O., G.P.; validation: J.S.E.L., S.L.C., G.P.; visualization: A.T., J.S.E.L., G.P.; writing: A.T., G.P.

Funding: This work was supported by the Research Support (WBS: C-141-000-097-001).

Conflicts of Interest: The authors declare no conflicts of interest. The funders had no role in the design of the study; in the collection, analyses, or interpretation of data; in the writing of the manuscript, or in the decision to publish the results.

\section{References}

1. Stewart, B.W.; Wild, C.P. World Cancer Report 2014; WHO: Geneva, Switzerland, 2014.

2. Valery, P.C.; Laversanne, M.; Clark, P.J.; Petrick, J.L.; McGlynn, K.A.; Bray, F. Projections of primary liver cancer to 2030 in 30 countries worldwide. Hepatology 2018, 67, 600-611. [CrossRef] [PubMed]

3. Torre, L.A.; Bray, F.; Siegel, R.L.; Ferlay, J.; Lortet-Tieulent, J.; Jemal, A. Global cancer statistics, 2012. CA Cancer J. Clin. 2015, 65, 87-108. [CrossRef] [PubMed]

4. Arnold, M.; Sierra, M.S.; Laversanne, M.; Soerjomataram, I.; Jemal, A.; Bray, F. Global patterns and trends in colorectal cancer incidence and mortality. Gut 2017, 66, 683-691. [CrossRef] 
5. Sakowicz-Burkiewicz, M.; Kitowska, A.; Grden, M.; Maciejewska, I.; Szutowicz, A.; Pawelczyk, T. Differential effect of adenosine receptors on growth of human colon cancer HCT 116 and HT-29 cell lines. Arch. Biochem. Biophys. 2013, 533, 47-54. [CrossRef] [PubMed]

6. Stemmer, S.M.; Shani, A.; Klein, B.; Silverman, M.H.; Lorber, I.; Farbstein, M.; Shmueli, E.; Figer, A. A phase II, multi-center study of a new non-cytotoxic $\mathrm{A}_{3}$ adenosine receptor agonist CF101, dose-finding (randomized blinded) in patients (pts)with refractory metastatic colorectal cancer. J. Clin. Oncol. 2004, 22 (Suppl. 14), 3153. [CrossRef]

7. Bar-Yehuda, S.; Madi, L.; Silberman, D.; Gery, S.; Shkapenuk, M.; Fishman, P. CF101, An Agonist to the $A_{3}$ Adenosine Receptor, Enhances the Chemotherapeutic Effect of 5-Fluorouracil in a Colon Carcinoma Murine Model. Neoplasia 2005, 7, 85-90. [CrossRef] [PubMed]

8. Borea, P.A.; Varani, K.; Vincenzi, F.; Baraldi, P.G.; Tabrizi, M.A.; Merighi, S.; Gessi, S. The A 3 Adenosine Receptor: History and Perspectives. Pharmacol. Rev. 2015, 67, 74-102. [CrossRef] [PubMed]

9. Gessi, S.; Cattabriga, E.; Avitabile, A.; Gafa, R.; Lanza, G.; Cavazzini, L.; Bianchi, N.; Gambari, R.; Feo, C.; Liboni, A.; et al. Elevated Expression of $\mathrm{A}_{3}$ Adenosine Receptors in Human Colorectal Cancer Is Reflected in Peripheral Blood Cells. Clin. Cancer Res. 2004, 10, 5895-5901. [CrossRef]

10. Madi, L.; Ochaion, A.; Rath-Wolfson, L.; Bar-Yehuda, S.; Erlanger, A.; Ohana, G.; Harish, A.; Merimski, O.; Barer, F.; Fishman, P. The $\mathrm{A}_{3}$ Adenosine Receptor Is Highly Expressed in Tumor versus Normal Cells. Potential Target for Tumor Growth Inhibition. Clin. Cancer Res. 2004, 10, 4472-4479. [CrossRef]

11. Panjehpour, M.; Hemati, S.; Forghani, M.A. Expression of $A_{1}$ and $A_{3}$ Adenosine Receptors in Human Breast Tumors. Tumori J. 2012, 98, 137-141. [CrossRef]

12. Trincavelli, M.L.; Tuscano, D.; Marroni, M.; Falleni, A.; Gremigni, V.; Ceruti, S.; Abbracchio, M.P.; Jacobson, K.A.; Cattabeni, F.; Martini, C. A 3 Adenosine Receptors in Human Astrocytoma Cells: Agonist-Mediated Desensitization, Internalization, and Down-Regulation. Mol. Pharmacol. 2002, 62, 1373-1384. [CrossRef] [PubMed]

13. Kohno, Y.; Sei, Y.; Koshiba, M.; Kim, H.O.; Jacobson, K.A. Induction of Apoptosis in HL-60 Human Promyelocytic Leukemia Cells by Adenosine $\mathrm{A}_{3}$ Receptor Agonists. Biochem. Biophys. Res. Commun. 1996, 219, 904-910. [CrossRef] [PubMed]

14. Llovet, J.; Zucman-Rossi, J.; Pikarsky, E. Hepatocellular carcinoma [serial online]. Nat. Rev. Dis. Primers 2016, 2, 16018. [CrossRef] [PubMed]

15. Stemmer, S.M.; Benjaminov, O.; Medalia, G.; Ciuraru, N.B.; Silverman, M.H.; Bar-Yehuda, S.; Fishman, S.; Harpaz, Z.; Farbstein, M.; Cohen, S.; et al. CF102 for the Treatment of Hepatocellular Carcinoma: A Phase I/II, Open-Label, Dose-Escalation Study. Oncologist 2013, 18, 25-26. [CrossRef] [PubMed]

16. Shao, Y.-M.; Ma, X.; Paira, P.; Tan, A.; Herr, D.R.; Lim, K.L.; Ng, C.H.; Venkatesan, G.; Klotz, K.N.; Federico, S.; et al. Discovery of indolylpiperazinylpyrimidines with dual-target profiles at adenosine A2A and dopamine D2 receptors for Parkinson's disease treatment. PLoS ONE 2018, 13, e0188212. [CrossRef]

17. Thompson, M.J.; Louth, J.C.; Ferrara, S.; Sorrell, F.J.; Irving, B.J.; Cochrane, E.J.; Meijer, A.J.; Chen, B. Structure-Activity Relationship Refinement and Further Assessment of Indole-3-glyoxylamides as a Lead Series against Prion Disease. ChemMedChem 2011, 6, 115-130. [CrossRef]

18. Johansson, H.; Urruticoechea, A.; Larsen, I.; Sejer Pedersen, D. A Scalable Method for Regioselective 3-Acylation of 2-Substituted Indoles under Basic Conditions. J. Org. Chem. 2015, 80, 471-481. [CrossRef]

19. Gitto, R.; De Luca, L.; Ferro, S.; Russo, E.; De Sarro, G.; Chisari, M.; Ciranna, L.; Alvarez-Builla, J.; Alajarin, R.; Buemi, M.R.; et al. Synthesis, modelling and biological characterization of 3-substituted-1H-indoles as ligands of GluN2B-containing N-methyl-d-aspartate receptors. Bioorg. Med. Chem. 2014, 22, 1040-1048. [CrossRef]

20. Wang, B.-L.; Shi, Y.-X.; Zhang, S.-J.; Ma, Y.; Wang, H.-X.; Zhang, L.-Y.; Wei, W.; Liu, X.H.; Li, Y.H.; Li, Z.M.; et al. Syntheses, biological activities and SAR studies of novel carboxamide compounds containing piperazine and arylsulfonyl moieties. Eur. J. Med. Chem. 2016, 117, 167-178. [CrossRef]

21. Gilbert, E.J.; Greenlee, W.J.; Miller, M.W.; Scott, J.D.; Stamford, A.W.; Inventors; USA. Assignee. Substituted Piperazines as CB1 Antagonists and Their Preparation. U.S. Patent US20130072468A1, 21 March 2013.

22. Inoue, A.; Ishiguro, J.; Kitamura, H.; Arima, N.; Okutani, M.; Shuto, A.; Higashiyama, S.; Ohwada, T.; Arai, H.; Makide, K.; et al. TGF $\alpha$ shedding assay: An accurate and versatile method for detecting GPCR activation. Nat. Methods 2012, 9, 1021. [CrossRef]

23. Park, K.-S.; Hoffmann, C.; Kim, H.O.; Padgett, W.L.; Daly, J.W.; Brambilla, R.; Motta, C.; Abbracchio, M.P.; Jacobson, K.A. Activation and desensitization of rat $\mathrm{A}_{3}$-adenosine receptors by selective adenosine derivatives and xanthine-7-ribosides. Drug Dev. Res. 1998, 44, 97-105. [CrossRef] 
24. Storme, J.; Cannaert, A.; Van Craenenbroeck, K.; Stove, C.P. Molecular dissection of the human $\mathrm{A}_{3}$ adenosine receptor coupling with $\beta$-arrestin2. Biochem. Pharmacol. 2018, 148, 298-307. [CrossRef] [PubMed]

25. Bar-Yehuda, S.; Stemmer, S.M.; Madi, L.; Castel, D.; Ochaion, A.; Cohen, S.; Barer, F.; Zabutti, A.; Perez-Liz, G.; Del Valle, L.; et al. The $\mathrm{A}_{3}$ adenosine receptor agonist CF102 induces apoptosis of hepatocellular carcinoma via de-regulation of the Wnt and NF-KB signal transduction pathways. Int. J. Oncol. 2008, 33, 287-295. [PubMed]

26. Gao, Z.-G.; Jacobson, K.A. Translocation of arrestin induced by human $\mathrm{A}_{3}$ adenosine receptor ligands in an engineered cell line: Comparison with G protein-dependent pathways. Pharmacol. Res. 2008, 57, 303-311. [CrossRef] [PubMed]

27. Fishman, P.; Bar-Yehuda, S.; Ardon, E.; Rath-Wolfson, L.; Barrer, F.; Ochaion, A.; Madi, L. Targeting the $\mathrm{A}_{3}$ adenosine receptor for cancer therapy: Inhibition of prostate carcinoma cell growth by $\mathrm{A}_{3} \mathrm{AR}$ agonist. Anticancer Res. 2003, 23, 2077-2084. [PubMed]

28. Kim, S.-K.; Riley, L.; Abrol, R.; Jacobson, K.A.; Goddard, W.A., III. Predicted structures of agonist and antagonist bound complexes of adenosine $\mathrm{A}_{3}$ receptor. Proteins 2011, 79, 1878-1897. [CrossRef] [PubMed]

29. Ciancetta, A.; Jacobson, K.A. Structural Probing and Molecular Modeling of the $\mathrm{A}_{3}$ Adenosine Receptor: A Focus on Agonist Binding. Molecules 2017, 22, 449. [CrossRef]

30. Dal Ben, D.; Buccioni, M.; Lambertucci, C.; Marucci, G.; Thomas, A.; Volpini, R.; Cristalli, G. Molecular modeling study on potent and selective adenosine $A_{3}$ receptor agonists. Bioorg. Med. Chem. 2010, 18, 7923-7930. [CrossRef]

31. Tosh, D.K.; Ciancetta, A.; Warnick, E.; O'Connor, R.; Chen, Z.; Gizewski, E.; Crane, S.; Gao, Z.G.; Auchampach, J.A.; Salvemini, D.; et al. Purine (N)-Methanocarba Nucleoside Derivatives Lacking an Exocyclic Amine as Selective $\mathrm{A}_{3}$ Adenosine Receptor Agonists. J. Med. Chem. 2016, 59, 3249-3263. [CrossRef]

32. Gao, Z.-G.; Kim, S.-K.; Biadatti, T.; Chen, W.; Lee, K.; Barak, D.; Kim, S.G.; Johnson, C.R.; Jacobson, K.A. Structural Determinants of $\mathrm{A}_{3}$ Adenosine Receptor Activation: Nucleoside Ligands at the Agonist/Antagonist Boundary. J. Med. Chem. 2002, 45, 4471-4484. [CrossRef]

33. Gao, Z.-G.; Chen, A.; Barak, D.; Kim, S.-K.; Müller, C.E.; Jacobson, K.A. Identification by Site-directed Mutagenesis of Residues Involved in Ligand Recognition and Activation of the Human $\mathrm{A}_{3}$ Adenosine Receptor. J. Biol. Chem. 2002, 277, 19056-19063. [CrossRef] [PubMed]

34. Jacobson, K.A.; Kim, H.S.; Ravi, G.; Kim, S.-K.; Lee, K.; Chen, A.; Chen, W.; Kim, S.; Barak, D.; Liang, B.T. Engineering of $\mathrm{A}_{3}$ adenosine and P2Y nucleotide receptors and their ligands. Drug Dev. Res. 2003, 58, 330-339. [CrossRef]

35. Pandy-Szekeres, G.; Munk, C.; Tsonkov, T.M.; Mordalski, S.; Harpsoe, K.; Hauser, A.S.; Bojarski, A.J.; Gloriam, D.E. GPCRdb in 2018: Adding GPCR structure models and ligands. Nucleic Acids Res. 2018, 46, D440-D446. [CrossRef] [PubMed]

36. Jacobson, M.P.; Pincus, D.L.; Rapp, C.S.; Day, T.J.F.; Honig, B.; Shaw, D.E.; Friesner, R.A. A hierarchical approach to all-atom protein loop prediction. Proteins 2004, 55, 351-367. [CrossRef] [PubMed]

37. Yu, J.; Zhao, L.X.; Park, J.; Lee, H.W.; Sahu, P.K.; Cui, M.; Moss, S.M.; Hammes, E.; Warnick, E.; Gao, Z.G.; et al. N6-Substituted 5'-N-Methylcarbamoyl-4'-selenoadenosines as Potent and Selective $\mathrm{A}_{3}$ Adenosine Receptor Agonists with Unusual Sugar Puckering and Nucleobase Orientation. J. Med. Chem. 2017, 60, 3422-3437. [CrossRef] [PubMed]

38. Laskowski, R.A.; MacArthur, M.W.; Moss, D.S.; Thornton, J.M. PROCHECK: A program to check the stereochemical quality of protein structures. J. Appl. Crystallogr. 1993, 26, 283-291. [CrossRef]

39. Schrödinger Release 2018-3: LigPrep; Schrödinger, LLC: New York, NY, USA, 2018.

40. Schrödinger Release 2018-3: Epik; Schrödinger, LLC: New York, NY, USA, 2018.

41. Schrödinger Release 2018-3: Schrödinger Suite 2018-3 Induced Fit Docking Protocol; Glide, Schrödinger, LLC: New York, NY, USA, 2016; Prime, Schrödinger, LLC: New York, NY, USA, 2018.

Sample Availability: Not available. 